NBER WORKING PAPER SERIES

\title{
OLD EUROPE AGES: \\ REFORMS AND REFORM BACKLASHES
}

\author{
Axel H. Boersch-Supan \\ Alexander Ludwig \\ Working Paper 15744 \\ http://www.nber.org/papers/w15744
NATIONAL BUREAU OF ECONOMIC RESEARCH
1050 Massachusetts Avenue
Cambridge, MA 02138
February 2010

This paper was prepared for the NBER Conference on "Demography and the Economy", Yountville, California, 11-12 April 2008. We thank Alan Auerbach, Francesco Billari, John Pencavel, Sam Preston, Warren Sanderson, Syl Schieber, John Shoven, Guido Tabellini, and Michele Tertilt for helpful comments on an earlier version. Financial support was provided by the Deutsche Forschungsgemeinschaft, the Land Baden Württemberg, and the German Association of Insurers. The usual disclaimer applies. The views expressed herein are those of the authors and do not necessarily reflect the views of the National Bureau of Economic Research.

NBER working papers are circulated for discussion and comment purposes. They have not been peerreviewed or been subject to the review by the NBER Board of Directors that accompanies official NBER publications.

(C) 2010 by Axel H. Boersch-Supan and Alexander Ludwig. All rights reserved. Short sections of text, not to exceed two paragraphs, may be quoted without explicit permission provided that full credit, including $\odot$ notice, is given to the source. 
Old Europe ages: Reforms and Reform Backlashes

Axel H. Boersch-Supan and Alexander Ludwig

NBER Working Paper No. 15744

February 2010

JEL No. D13,E27,F16,F21,H55,J1,J21

\begin{abstract}
$\underline{\text { ABSTRACT }}$
The extent of the demographic changes in Europe is dramatic and will deeply affect future labor, financial and goods markets. The expected strain on public budgets and especially social security has already received prominent attention, but aging poses many other economic challenges that threaten growth and living standards if they remain unaddressed.

This paper focuses on three large Continental European countries: France, Germany, and Italy. These countries have large pay-as-you-go pension systems and vulnerable labor markets. At the same time, they show remarkable resistance against pension and labor market reform. While there is no shortage of reform proposals to address population aging, most of those focused on pension and labor market reform, little is known about behavioral reactions to such reforms.

This paper therefore sheds light on the potential benefits of pension and labor market reform for growth and living standards, taking into account behavioral reactions to specific reforms. Which behavioral reactions will strengthen, which will weaken reform policies? Can Old Europe maintain its standard of living even if behavioral reactions offset some of the current reform efforts?
\end{abstract}

Axel H. Boersch-Supan

Mannheim Research Institute for the

Economics of Aging

University of Mannheim

Building L13, 17

D-68131 Mannheim

GERMANY

and NBER

axel@boersch-supan.de

Alexander Ludwig

University of Cologne

ludwig@wiso.uni-koeln.de 


\section{Introduction}

While aging is global, there are marked international differences in the speed and the extent of the aging processes. Even within the industrialized countries, differences are large. Europe and Japan have already a much older population than North-America. Italy and Germany, in turn, are aging faster than France and Great Britain. Italy and Germany are projected to shrink in population size; even more dramatic is the shrinkage of the labor force between 2010 and 2035 when the German and Italian babyboom generations will retire. To the extent that labor force shrinkage precedes population shrinkage, these countries will face steeply falling support ratios (workers per consumers). One likely implication is slower economic growth and, in the worst case, stagnating or falling standards of living if the force of aging is stronger than the force of productivity growth.

This paper has two broad aims. First, it shows that pension and labor market reforms have the potential to mitigate much of the negative implications of population aging. Hence, there is a good reason to bear the short-run costs of reforms in exchange for the long-run benefits. Second, the paper models potential backlashes to reform in order to provide a more realistic assessment of what might be the outcome of the politically complicated reform process in Europe.

The paper is part of a research agenda that analyzes the aging process and its macroeconomic implications in Continental Europe, focusing on its three largest countries, France, Germany, and Italy, the core of Old Europe. These countries have large public budgets and pay-as-yougo financed social security systems. Their unsustainability has already received prominent attention. In addition, these countries have labor markets characterized by low participation rates, high unemployment, and high wages. They are particularly vulnerable to the challenges of globalization due to the high tax and contribution burden in total labor compensation. In spite of these problems, France, Germany, and Italy have been remarkably resistant to labor market and pension reform. If governments anyway manage to push such reforms through parliament, workers may thus react adversely and undo at least some of the expected effects of the reforms. The main questions posed in this paper are therefore: What can pension and labor market reforms ideally achieve? What are possible behavioral reactions to reform policies? Which direction will they take and how large are they? And ultimately: Can Old Europe maintain its high living standards even if behavioral reactions offset some of the current reform efforts? 
Some behavioral reactions will strengthen reform. A good example is raising the statutory retirement age. It has direct effects on the labor supply by bringing older individuals to the labor market. Indirect effects emerge from endogenous labor supply reactions, e.g., through incentive effects generated by the tax and contribution burden that actuarially unfair social security systems impose on households. Raising the retirement age will lower social security contributions in such pension systems. In response to rising net wages, labor supply may then increase at all ages.

There are, however, also behavioral effects that weaken policy reforms. To take up the same example, older workers, now forced to work longer, may exploit part-time opportunities given by the pension system. In some countries (e.g., Finland and Germany) such opportunities led to a very early transition to part time work with the perverse result that in some sectors hours supplied actually decreased in response to pension reform. Along the same line, encouraging female labor supply, e.g. through public provision of day care facilities, may precipitate a decrease in male labor supply. This within-household substitution would be perfectly rational if households desire joint leisure and joint household production.

Little is known about these behavioral reactions. One of the key issues taken up in this paper is therefore to model and calibrate behavioral reactions to reform. Which behavioral reactions will strengthen, which will weaken reform policies? What are their quantitative effects?

We will build a simple model of reforms and reform backlashes into an overlapping generations model of the Auerbach, Kotlikoff and Skinner (1983)/Auerbach and Kotlikoff (1987) type, extended to a multi-country version (Börsch-Supan, Ludwig and Winter, 2007). ${ }^{1}$ As a particular feature of our model, we add to the model the distinction between exogenous labor supply components (as key results of labor market and pension reform) and endogenous labor supply components (in order to represent possible reform backlash). To keep the language simple, we call the exogenous labor supply component "labor force participation", and the endogenous labor supply component “working hours”. This language is metaphorical as we are well aware that both labor force participation and working hours have endogenous as well as exogenous components.

\footnotetext{
1 Similar multi-country OLG models have been developed, among others, by Feroli (2002), Henriksen (2002), Brooks (2003), Domeij and Floden (2006), Attanasio, Kitao and Violante (2006, 2007) and Krüger and Ludwig (2007).
} 
The metaphorical language chosen comes from our thinking of labor market and pension reforms as lifting institutional constraints. Typical constraints are a minimum labor market entry age generated by the school system, constraining the labor force participation of the young; an early labor market exit age generated by the pension system, effectively constraining the labor force participation of the old; inflexible working hours and unavailable day care facilities, constraining female labor force participation. This view of lifting restrictions motivates our modeling strategy and the language behind it: labor market and pension reforms are represented by exogenous changes of labor supply at the extensive margin (the number of working persons in an economy).

Households then are modeled to respond to the changes of labor supply by changing their working hours (the intensive margin of labor supply). Endogenous hours' supply may increase, e.g., if distorting social security taxes and contributions decline as an implication of pension reform. The opposite reaction is also possible: endogenous hours' supply may decrease in response to an exogenous change of the number of working persons if there is intrahousehold substitution between the number of persons working and the hours worked by each person.

Another important feature of our model is its multi-country nature. No country in Continental Europe is even approximately modeled by a closed economy. France, Germany, and Italy have large export sectors and considerable foreign direct investments. These provide a second source of opportunities during the global aging process: not all income needs to come from domestic production, and GNP may become substantially larger than GDP if foreign direct investments create large returns. We complement France, Germany, and Italy as countries which save more than they invest with the U.S. representing the rest of the world currently absorbing the Continental European savings.

While this feature is important for a credible quantification of our pension and labor market reform analysis, it is not the main focus of this paper. We refer to a sister paper, BörschSupan, Ludwig and Winter (2007), which analyzes the resulting international capital flows and the associated rate of return developments, including the "asset meltdown hypothesis”.

The key results of our paper rest on a set of three-way comparisons that are best imagined by a two-by-two-by-two table. The first dimension reflects labor market policies. One extreme is the complete failure to adapt those institutional restrictions that keep labor force participation so low in France, Germany, and Italy. The result are unchanged low labor force participation 
rates by age and gender also in the future. The polar case, for some an extreme, is the adaptation of all societal systems from kindergarten to retirement policies to increase age and gender specific labor force participation rates across the board.

As a second dimension, we model two extreme positions of pension policy. One extreme is a fully-funded, voluntary private accounts system with no distortions and perfect intertemporal consumption smoothing. The other extreme is a pay-as-you-go pension system with flat benefits financed by a contribution that is perceived as a pure tax with the associated labor supply distortions.

Finally, the third dimension in these comparisons isolates behavioral effects. One extreme is a fixed hours' supply by each working individual. As polar case, we derive a supply function of working hours which is responsive to wages net of taxes and contributions, but also to household labor participation.

Our paper shows that direct quantity and indirect behavioral effects are large. They both significantly affect economic growth and living standards. Due to strong interaction effects between pension system and labor markets, a smart combination of pension policy and adaptation of institutions related to the labor market can do more than each policy in isolation. We show that they can offset the effects of population aging on economic growth and living standards. On balance, however, behavioral effects dampen such reform efforts. Taking positive and negative behavioral effects into account, a combination of many policy measures is necessary in order to keep per capita consumption from falling behind the secular growth path.

The rest of the paper is structured as follows. Section 2 briefly sets the demographic background. Section 3 describes the current labor market situation and our labor market reform scenarios. Section 4 presents the multi-country computational general equilibrium model with a combination of exogenous and endogenous labor supply components. Section 5 delivers our main results in the two-by-two-by-two table set up. We vary the institutional framework of labor markets and pensions in order to investigate the interactions between pension and employment policies and the behavioral reactions to pension and labor market reform. Since higher old-age labor force participation raises issues of age-specific productivity, they are briefly addressed in Section 6. Section 7 concludes. 


\section{Demography}

While the patterns of population aging are similar in most countries, timing and extent differ substantially. The United States is considerably younger and will age later and to a slower extent than the EU, especially Germany and Italy. This is most graphically depicted in the changing population pyramids of our four countries between 2000 and 2050, see figure 1.

\section{FIGURE 1: Population ageing in France, Germany, Italy, and the U.S., 2000 and 2050}

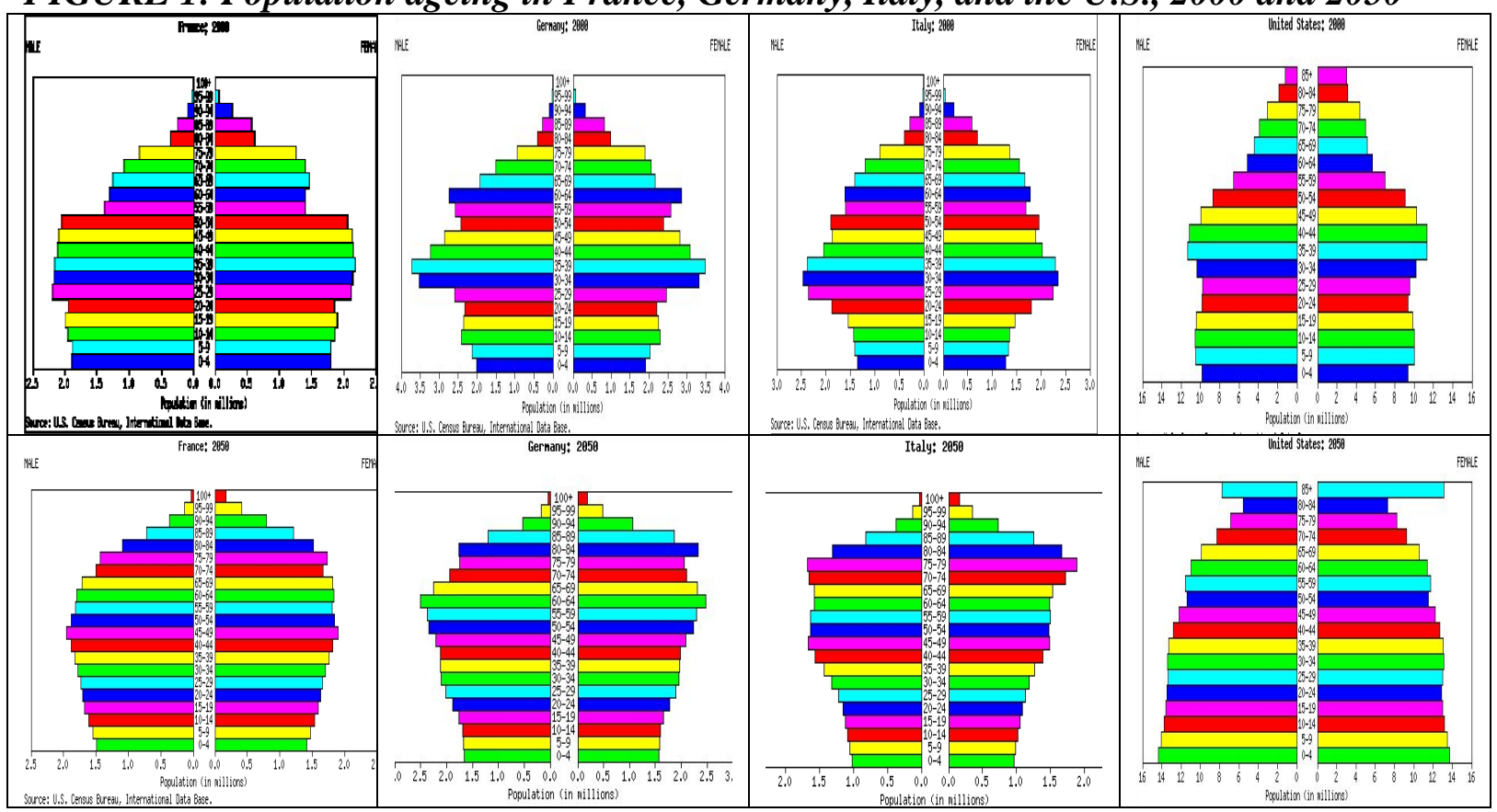

Source: U.S. Bureau of the Census, International Data Base, http://www.census.gov/ipc/www/idb/pyramids.html

The differences are startling. While the U.S. population pyramid in 2050 features the normal large base, Germany and Italy have strongly inverted population pyramids. The French pyramids change only little between 2000 and 2050, with relatively small differences in cohort sizes up to age 70 . These differences can largely be attributed to different fertility rates (France and the U.S. have fertility rates close to the replacement level, see table 1), while Germany and Italy loose about a third of their population from generation to generation due to fertility rates that are below 1.4. 
TABLE 1: Fertility rates and life expectancy

\begin{tabular}{|l|c|c|c|c|}
\hline & $\begin{array}{c}\text { Total fertility } \\
\text { rate }\end{array}$ & $\begin{array}{c}\text { Life expectancy } \\
\text { at birth }\end{array}$ & $\begin{array}{c}\text { Healthy life ex- } \\
\text { pectancy }\end{array}$ & $\begin{array}{c}\text { Life expectancy } \\
\text { in year 2050 }\end{array}$ \\
\hline France & 1.89 & 80.3 & 71.3 & 86 \\
\hline Germany & 1.34 & 79.0 & 70.2 & 84 \\
\hline Italy & 1.29 & 80.4 & 71.0 & 87 \\
\hline U.S. & 2.10 & 77.8 & 67.6 & 83 \\
\hline
\end{tabular}

Source: Eurostat and U.S. Census (2008); OECD Health Data 2007; WHO (2006); and own computations.

Life expectancy also differs remarkably among the four countries. This is accentuated in the healthy life expectancy, a measure developed by WHO based on functional ability: it measures the expected age without functional limitation as defined by a set of disability indicators. Healthy life expectancy in France is almost four years higher than in the U.S. Note that in Europe healthy life expectancy is about 10 years higher than the average retirement age, providing some room for an increase in retirement age, see section 3.

We compute the future demography of the four countries based on three key assumptions. First, we provide projections of mortality based on a Lee-Carter decomposition, using past mortality rate changes derived from the Human Mortality Database (2008). Table 1 shows the resulting life expectancies in 2050 (column 5). They coincide with the current UN projections for Germany and the U.S., but are slightly higher for France and Italy (UN has age 85 compared while our projections yield age 86 and 87, respectively).

Second, we assume that fertility rates are exogenous and remain constant as given by table 1 . Third and similarly, we assume constant and exogenous migration flows, based on the current medium variant of the UN projections (France 100,000, Germany 150,000, Italy 135,000, and U.S. 1,100,000 net migrants per year) which is about the long-term average. It is important to note that these migration flows are small relative to the decline in the labor force projected in section 3 .

Figure 2 shows the total population aged 15 years and over which will be the base of our projections and simulations. It reflects the stark differences among the population pyramids that we have seen in figure 1. There will be population growth in France and the U.S. but significant decline in Germany and a somewhat smaller decline in Italy after 2020, mainly due to the higher expected migration to Italy. The fifth line represents the aggregate of France, Ger- 
many, and Italy which we will call EU-3 in order to represent the three largest Continental European countries.

FIGURE 2: Population 15 years and older, indexed to 2005=100\%

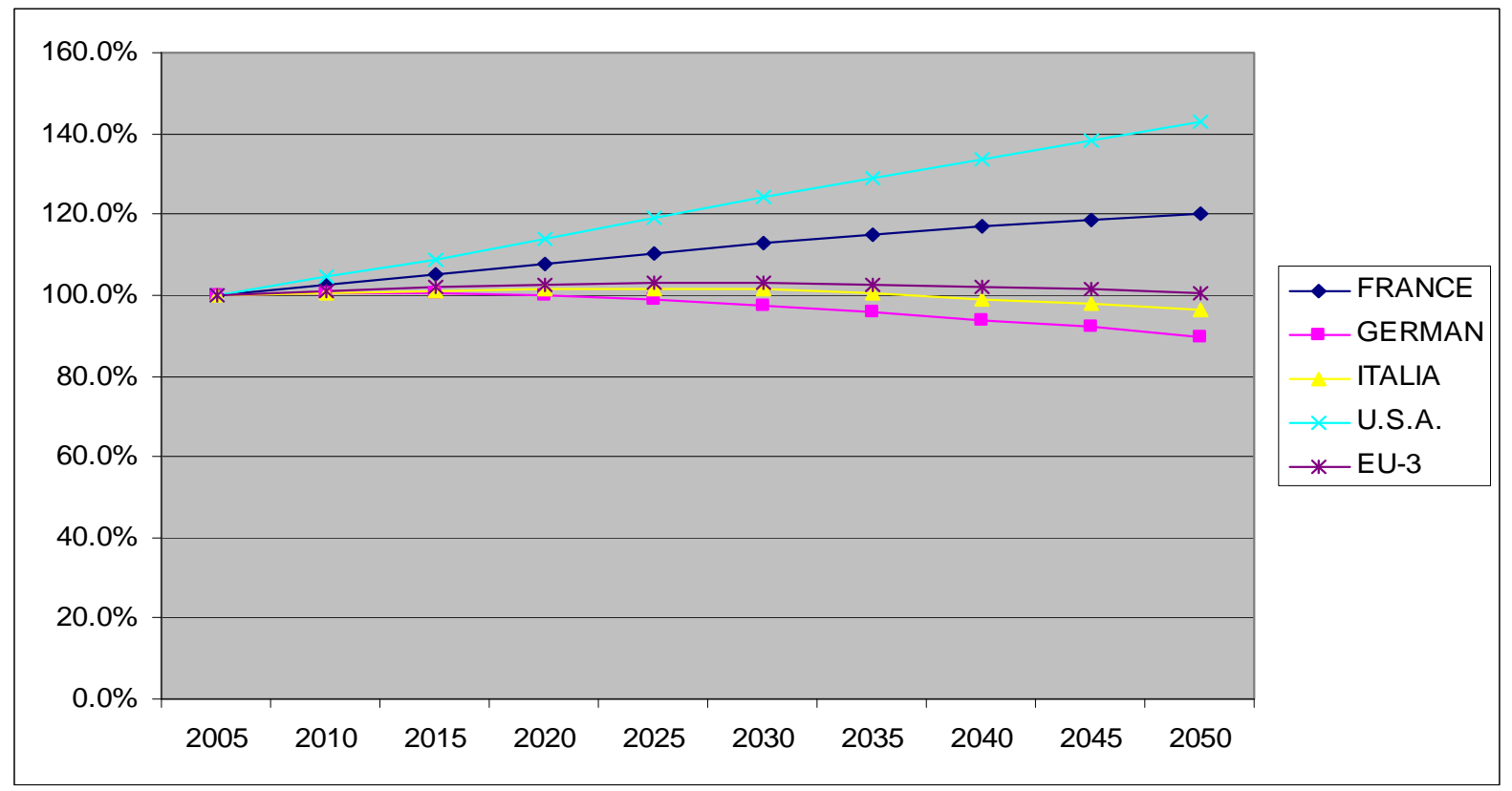

Source: Own projection based on assumptions detailed in text

Truly remarkable is the decline of the working age population (age 20-64), see figure 3. Relative to total population aged 15 and older, the U.S. will loose about $10 \%$ of their working age individuals between 2005 and 2050. In Italy, the loss is more than twice as high with 22\%. France is closer to U.S. and Germany closer to Italy, reflecting the fertility rates in table 1. 
FIGURE 3: Working age population as share of total population aged 15+, 2005=100\%

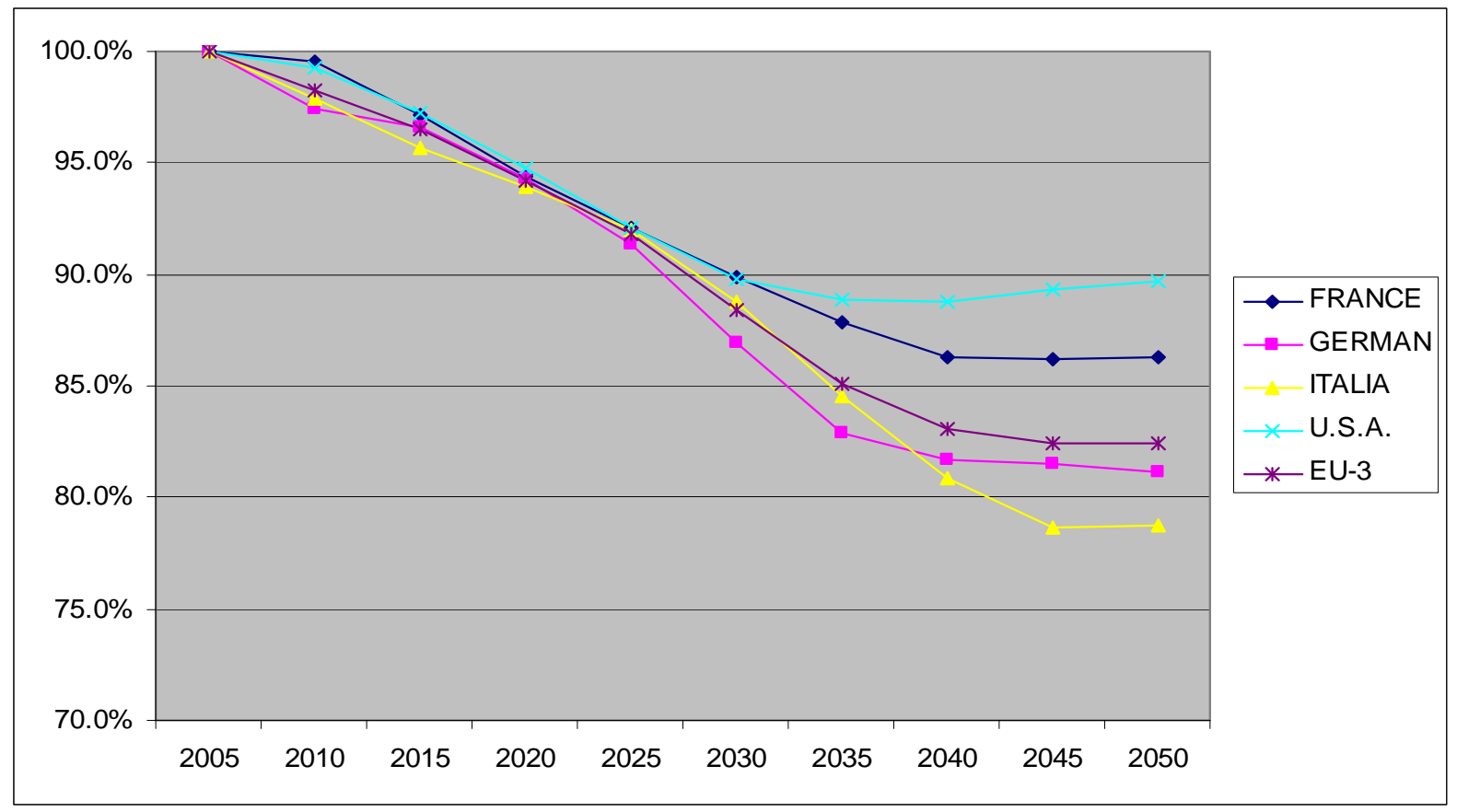

Source: Own projection based on assumptions detailed in text. Working age is age 20 to 64 .

\section{Employment and Labor Market Reforms}

Working age population is not equal to employment. The demographic differences, in particular those between Italy and the U.S., are dramatically amplified by the differences in labor force participation. Figure 4 shows the percentage of individuals employed in the population aged 15 and older. This is a variant of the "support ratio" reflecting the number of workers per adult consumer. U.S. support rates are much higher than the European ones. In Europe, Italy stands out with the lowest support ratio. Unlike to its demographic position, France shares the low labor force participation of Continental Europe; current French labor force participation rates are actually lower than the German ones. 


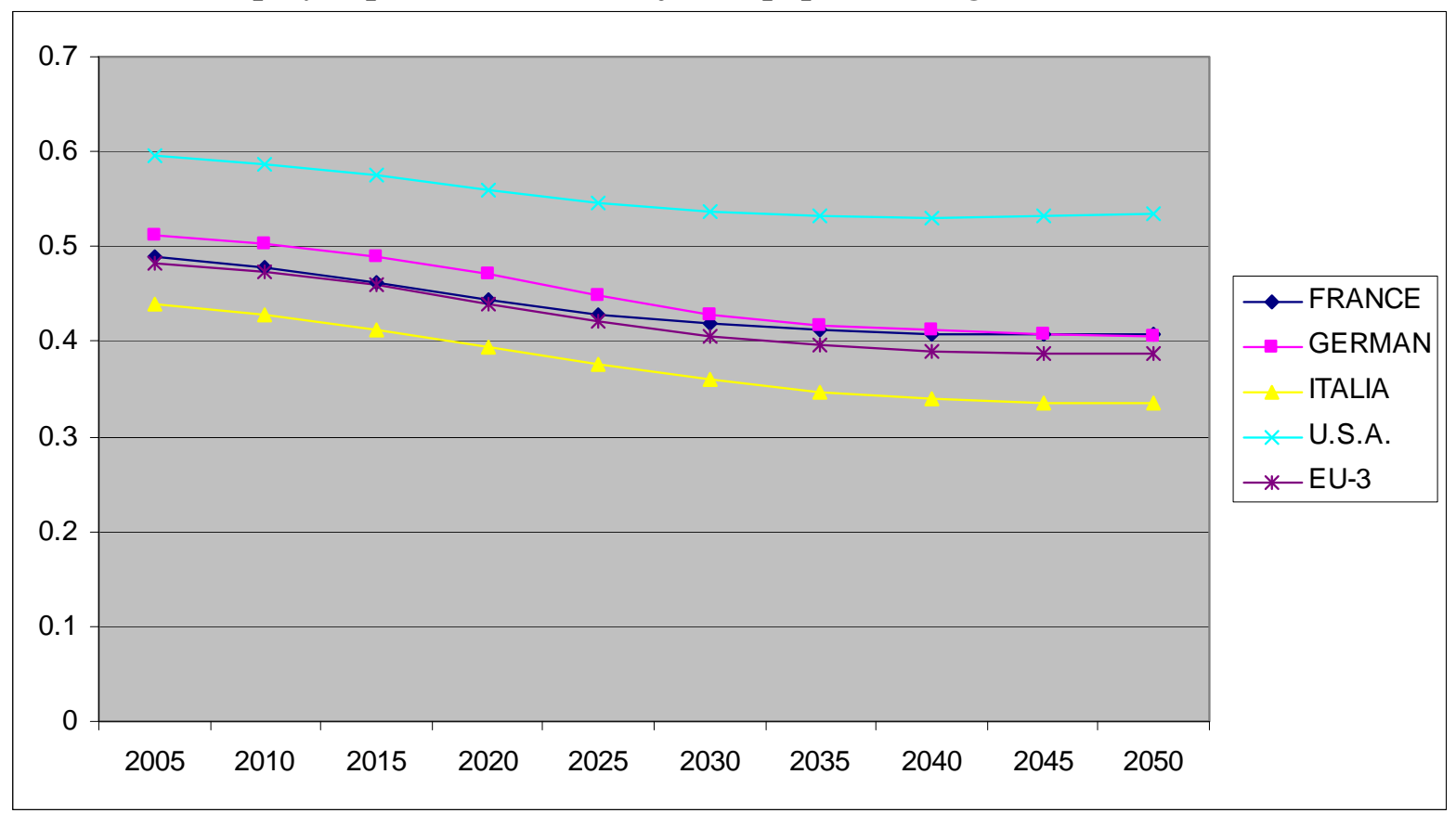

Source: Own projection based on 2005 labor force participation rates.

Figure 4 is based on the assumption of constant age and gender specific labor force participation rates. Given this assumption, Germany has about the same low support ratio in 2005 which the U.S. will have after 2040. In this sense, Germany is one generation ahead of the US when it concerns the macroeconomic balance between individuals in production and individuals who consume.

Figure 4 also shows that the decline of the support ratio, given the assumption of no behavioral changes, will be more pronounced in the three European countries than in the U.S. (24.3\% vs. 15.0\% between 2005 and 2050), aggravating the current differences of the support ratios among the four countries.

Aggregate employment is a results of labor market entry age, female labor force participation, unemployment rates, and labor market exit age, to name the four most important parameters. These parameters are strongly governed by institutional restrictions. Labor market entry age, e.g., is a function of the school system. Germany, e.g., has a regulations that generate late entries into the school system, a long duration in high schools and universities, and thus a late labor market entry age. Similarly, female labor force participation is a function of institutions such as kindergarten and afternoon school which tend to be provided by public entities in Europe. Unemployment is a function of the duration and generosity of unemployment compensation. Labor market exit, finally, is strongly governed by pension regulations that effec- 
tively make the early eligibility age also the effective age of labor market withdrawal. Our main point is, that from an individual's point of view, labor supply has important exogenous components which restrict possible endogenous labor supply decisions.

It is unlikely that these exogenous components remain unchanged over the course of population aging and the general change of society over the next two decades. We therefore define two polar scenarios representing the potential changes in the institutional framework restricting households' labor supply decisions:

- In the status quo scenario (STATQUO), age and gender specific labor force participation rates will remain as they are at baseline in 2005; this was the scenario underlying figure 4.

- The labor market reform scenario (LREFORM) includes four reform steps:

o RETAGE: an increase in the retirement age by 2 years;

o JOBENTRY: a decrease in the job entry age by 2 years;

o FEMLFP: an adaptation of female labor force participation rates to those of men;

o UNEMP: a reduction of unemployment to $40 \%$ of its current level.

The increments are motivated by actual policy proposals: in Germany, the statutory retirement age has been raised from 65 to 67 years in a serious of transitions until about 2020; in France and Italy, similar steps will follow with some delay. The change in the European high school and university system (the so called Bologna process) is expected to decrease duration in schooling by about 2 years. Finally, $40 \%$ of current unemployment represents the conventional estimate of the NAIRU (Ball and Mankiw, 2002).

These reform steps will be phased in linearly between 2010 and 2050. The increase in retirement age (the decrease in the job entry age) is modeled as a shift of the distribution of labor force participation rates by age to the right (to the left, respectively), thereby increasing the flat part of the distribution in the middle, see figure 5.

Overall, these reform steps do not appear to be overly radical; in fact, their combination would lead in 2040 to labor force participation rates fairly similar to those in Denmark today. Nevertheless, attempts to actually execute reforms with those goals have faced stiff opposition in France and Italy, and more recently and to a somewhat lesser extent also in Germany. 


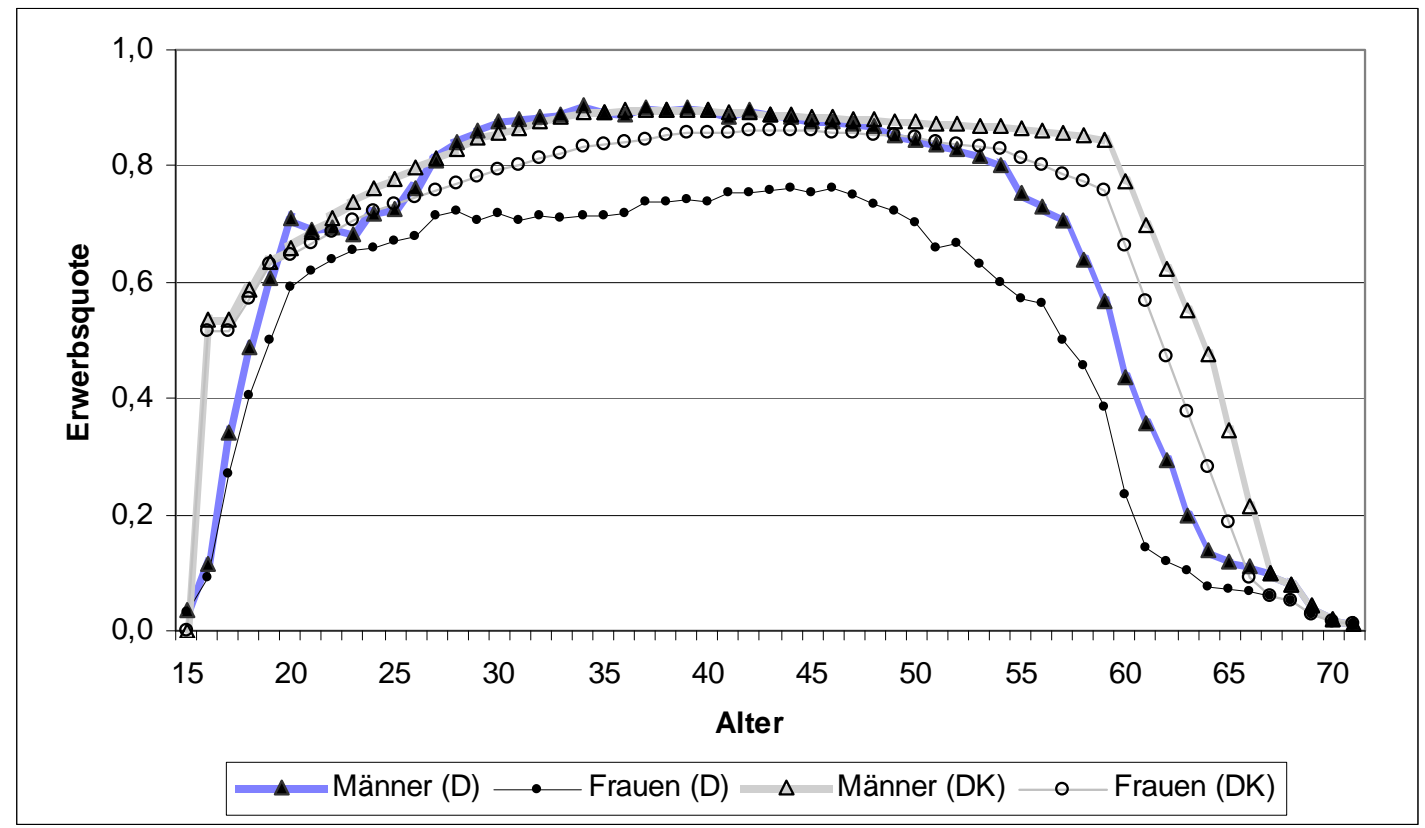

Source: Own computations based on the German Mikrozensus (www.destatis.de) and Statistics Denmark (www.statbank.dk).

Figure 6 displays the resulting trajectories of the number of working individuals. Each reform step is additive to the one before; hence, the trajectory labeled "UNEMP" corresponds to the LREFORM scenario of all four reform elements implemented.

The trajectories are very different across countries. France can easily compensate the slightly declining number of individuals of working age by a combination of two or three of the above policy changes, while Germany has no chance to offset the loss in working age population even with a combination of all four measures.

The three countries also differ in the efficacy of the four policy parameters. Note in particular Italy with a large jump if female labor force participation adapts to that of men. This is due to the very low female labor force participation currently in Italy. The irony is of course that, because Italy's pool of hitherto unused labor capacity (in particular women) is so large, tapping it provides a very large opportunity to counteract the effects of population aging. Italy, while aging more than Germany, is thus much better off than Germany which has less room to increase labor force participation. 
Lower labor input as indicated in these figures will most likely slow down Germany's and possibly also Italy's GDP growth. ${ }^{2}$ However, since total population will also decline, this does not necessarily imply that standards of living will fall. Figure 7 therefore divides the number of working persons by the population aged 15 and older, our support ratio. The main message is that a combination of the four policy scenarios can in all countries, more or less also in Germany and Italy, stabilize these countries' support ratio. This is a first very important message: lifting labor market constraints and tapping into the pool of currently unused labor can offset the force of aging in the three countries of Old Europe.

${ }^{2}$ Given the large share of labor in output and the history of total factor productivity, it is unlikely that productivity growth and capital accumulation can overcompensate the decline in labor force. 
FIGURE 6a: Employment, indexed to 2005=100\%, France

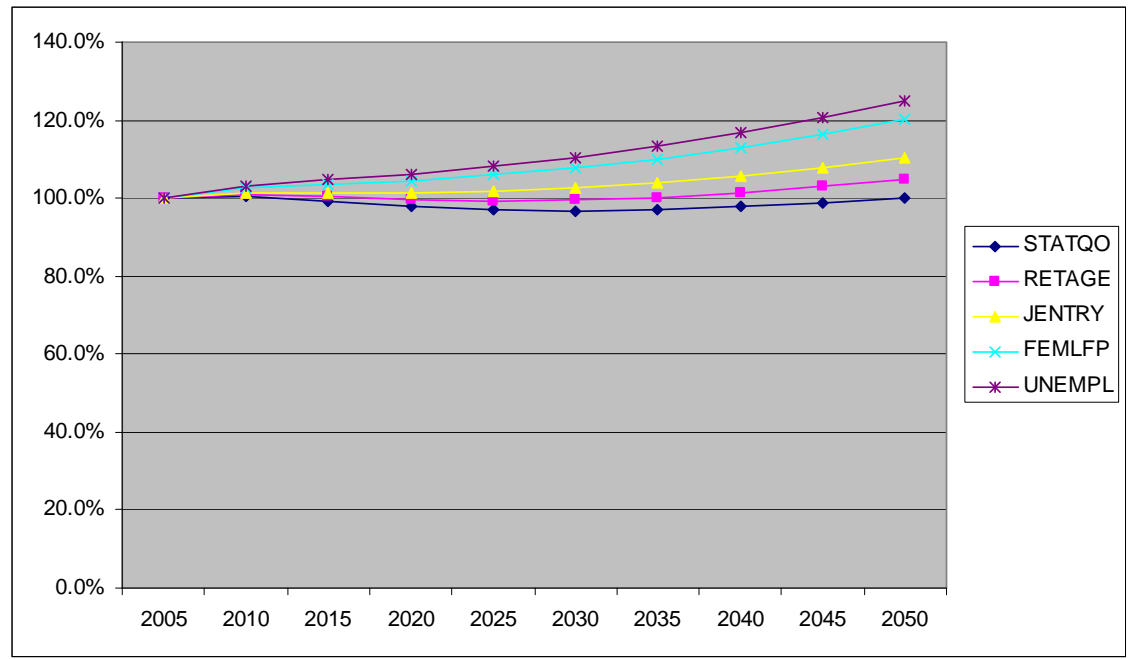

FIGURE 6b: Employment, indexed to 2005=100\%, Germany

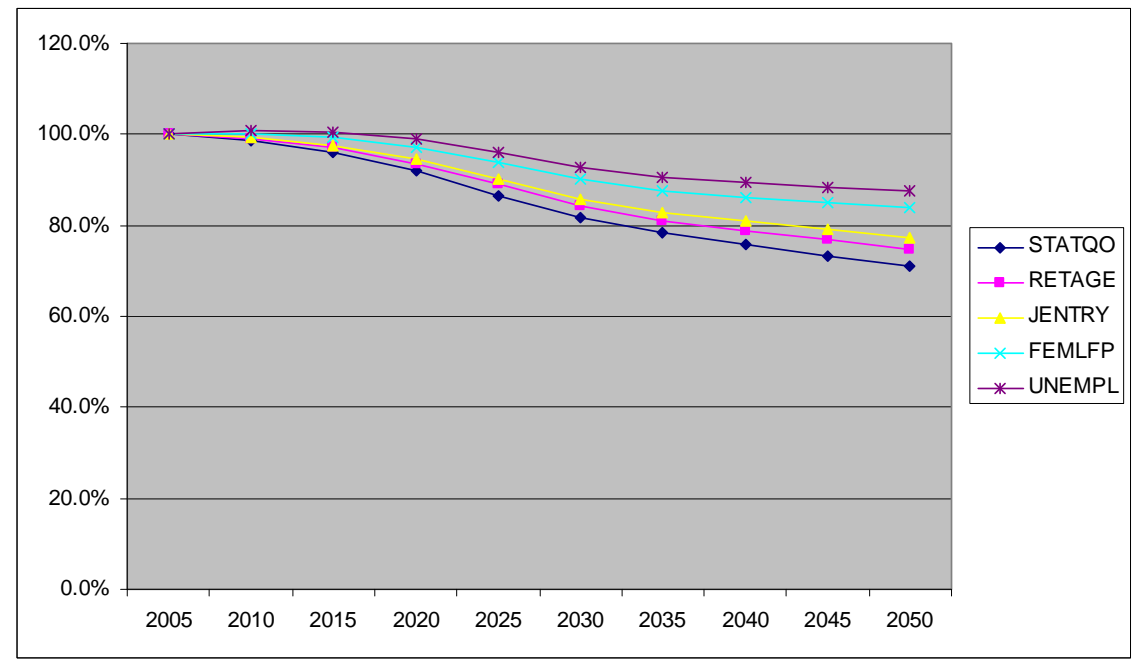

FIGURE 6c: Employment, indexed to 2005=100\%, Italy

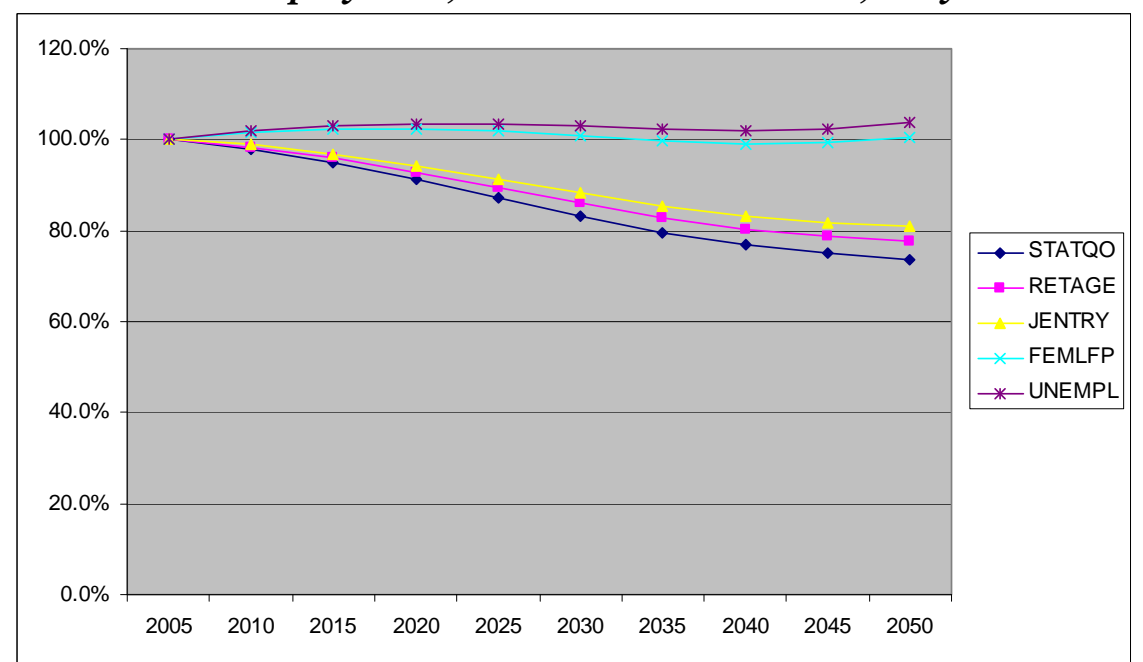

Source: Own calculations 
FIGURE 7a: Support ratio, indexed to $2005=100 \%$, France

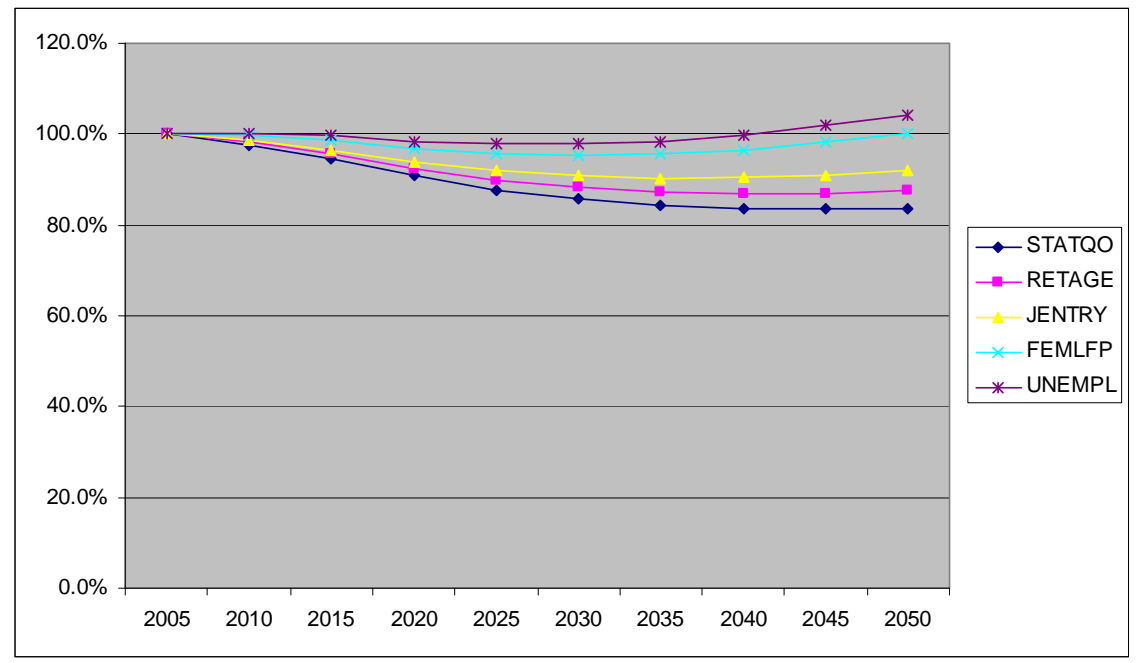

FIGURE 7b: Support ratio, indexed to $2005=100 \%$, Germany

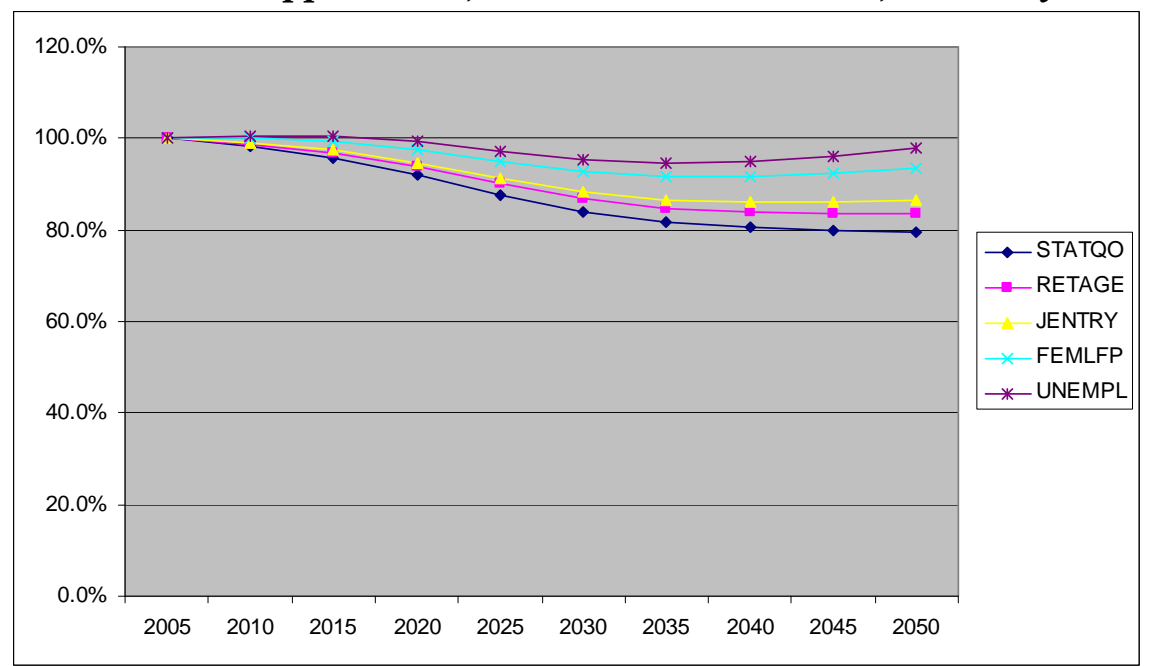

FIGURE 7c: Support ratio, indexed to 2005=100\%, Italy

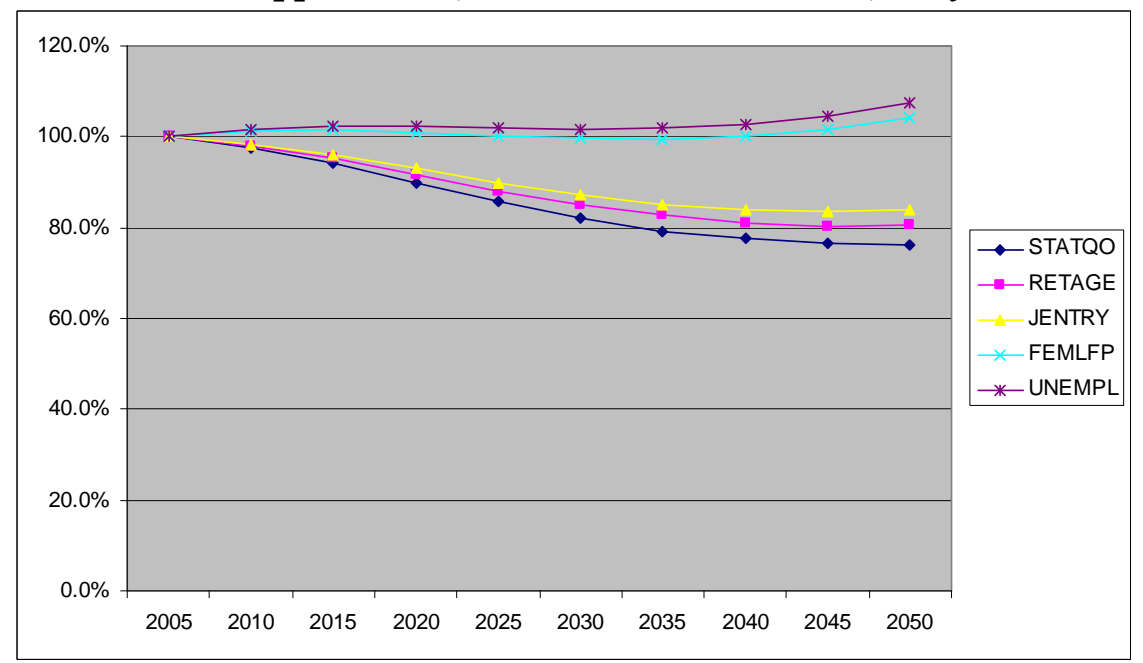

Note: Employment as share of population age 15+, own calculations 


\section{A dynamic open-economy macroeconomic model with exogenous labor force participation and endogenous hours' supply}

We now construct a dynamic open-economy macroeconomic model that allows us to analyze the effects of the labor market reforms described in the previous section on GDP and consumption per capita in an aging Europe. As described in the introduction, labor supply has an endogenous and an exogenous component. While we treat the reforms and the resulting variation in employment numbers as exogenous, households in our model endogenously adjust hours worked and may thus counteract parts of the labor market reforms.

Our main assumptions on this interplay between the exogenous variation of employment numbers and hours worked are as follows. We model the decision of a household with preferences over consumption and leisure. Total labor supply of a household of age $j$ as derived from the household's optimization is the product of exogenous employment numbers $l_{j}$, and the endogenous decision on hours worked at age $j, h_{j}$. The crucial difference between the two labor supply components is that hours worked may not exceed the time endowment (which we normalize to one) while employment numbers $l_{j}$, can take any positive value.

As the age-specific employment $l_{j}$ is exogenously increased, e.g., due to an increase in the retirement age, the household endogenously decreases hours worked, $h_{j}$. In the absence of any constraints, the two components of labor supply are perfect substitutes such that the exogenous variation of $l_{j}$ leaves the labor supply of the household unaffected. However, the exogenous variation of $l_{j}$ affects total effective labor supply for those households for whom the time endowment constraint is binding. As a consequence, the exogenous employment variation of $l_{j}$ has some effect on aggregate effective labor supply but the overall effect is substantially smaller than in an alternative specification of our model with fully exogenous labor supply where

\subsection{Demography}

Time in our model is discrete and extends from $t=0, \ldots, T$. Each model period $t$ reflects a time interval of 5 years. Our demographic projections, however, are more detailed with an annual periodicity. These detailed demographic projections form the background of our analysis. Demography is taken as exogenous. It represents one of the main driving force of our simulation model, in addition to exogenous changes in labor supply restrictions and pension policy changes. 
Households in our model economies enter economic life at age 15 which we denote by $j=0$. The maximum age is 100 years. Accordingly the maximum economic age, denoted by $J$, is 85. We assume that households give birth between ages $0, \ldots, j f$, the age of menopause. Accordingly, in each country $i$, the size of population of age $j$ in period $t, N_{t, j, i}$, is given recursively by

(1) $\quad N_{t+1, j+1, i}=N_{t, j, i} \varsigma_{t, j, i}$ for $j>0$ and $N_{t+1,0, i}=\sum_{j=0}^{j f} f_{t, j, i} N_{t, j, i}$

where $\varsigma_{t, j, i}$ denotes the age-specific conditional survival rate and $f_{t, j, i}$ the age-specific fertility rate. The resulting total fertility rates and life expectancies have been summarized in table 1 .

\subsection{Production}

The production sector in each country consists of a representative firm that uses a CobbDouglas production function given by

(2) $\quad Y_{t, i}=F\left(\Omega_{t, i}, K_{t, i}, L_{t, i}\right)=\Omega_{t, i} K_{t, i}^{\alpha} L_{t, i}^{1-\alpha}$,

where $K_{t, i}$ denotes the capital stock and $L_{t, i}$ is aggregate effective labor supply of country $i$ at time $t$. $\alpha$ is the capital share and $\Omega_{t, i}$ is the technology level of country $i$ growing at the exogenous rate $g$.

The firm's problem is static such that wages and interest rates are given by

(3) $w_{t, i}=\Omega_{t, i}(1-\alpha) k_{t}^{\alpha}$,

(4) $r_{t}=\alpha k_{t}^{\alpha}-\delta$,

where $k_{t}$ is the capital stock per efficient unit of labor and $\delta$ is the depreciation rate of capital.

\subsection{Households}

An exogenous fraction $l_{t, j, i}$ of each household supplies work. This fraction of the household endogenously decides on the hours of work $h_{t, j, i}$. The other fraction of the household, $1-l_{t, j, I}$, does not work and fully enjoys leisure. Accordingly, total labor supply of a household is given by the product of the two components, $l_{t, j, i} \cdot h_{t, j, i}$ and total leisure is therefore $1-l_{t, j, i} \cdot h_{t, j, i}$ whereby we restrict time endowment to one. 
The household derives utility from consumption $c_{t, j, i}$ and leisure $1-l_{t, j, i} h_{t, j, i}$ and the household's per period utility function is given by

$$
u\left(c_{t, j, i}, 1-h_{t, j, i} \cdot l_{t, j, i}\right)=\frac{1}{1-\theta}\left(c_{t, j, i}^{\phi}\left(1-l_{t, j, i} h_{t, j, i}\right)^{1-\phi}\right)^{1-\theta} .
$$

The maximization problem of a cohort born in period $t$ at $j=0$ is given by

$$
\max \sum_{j=0}^{J} \beta^{j} \pi_{t, j, i} u\left(c_{t+j, j, i}, 1-l_{t+j, j, i} h_{t+j, j, i}\right),
$$

where $\beta$ is the pure time discount factor. In addition to pure discounting, households discount future utility with their unconditional survival probability in period, $\pi_{t, j}=\prod_{k=0}^{j} s_{t+k, k}$.

A feature of our model is uncertainty about the time of death expressed in the term $\pi_{t, j, i}$ in equation (5). We assume that accidental bequests resulting from premature death are taxed by the government at a confiscatory rate and used for otherwise neutral government consumption. ${ }^{3}$ We do not include intended bequests in our model.

Labor productivity changes over the life-cycle according to age-specific productivity parameters $\varepsilon_{j}$. Hence, the age-specific wage is $w_{t, j, i}=w_{t, i} \cdot \varepsilon_{j}$.

Denoting total assets by $a_{t, j, i}$, maximization of the household's intertemporal utility is subject to a dynamic budget constraint given by

$$
a_{t+1, j+1, i}=a_{t, j}\left(1+r_{t}\right)+\lambda l_{t, j, i} h_{t, j, i} w_{t, j, i}\left(1-\tau_{t, i}\right)+(1-\lambda) p_{t, j, i}-c_{t, j, i}
$$

where $\lambda=1$ for $j=0, \ldots, j r$ and $\lambda=0$ for $j>j r$ and $j r$ is the exogenous retirement age. $\tau_{t, i}$ is the contribution rate to a PAYG financed public pension system and $p_{t, j, i}$ is pension income, see below.

Furthermore, maximization is subject to the constraint that hours worked are positive and may not exceed one, hence,

$$
\text { (7) } \quad 0 \leq h_{t, j, i} \leq 1 \text {. }
$$

\footnotetext{
${ }^{3}$ An alternative assumption would be to redistribute accidental bequests to the population according to some scheme. The redistribution would however not affect our results much and we therefore opted for this simplifying assumption.
} 
In the variant of our model with fully exogenous labor supply we replace the constraint (7) with the constraint that $h_{t, j, i}=1$ for all $t, j, i$.

\subsection{Pensions and pension reform}

The only purpose of the government in our model is to organize a prototypical Continental European public pension system that is pay-as-you-go financed and provides flat (i.e. not earnings-related) pension benefits. We assume that the budget of the pension system is balanced in all $t, i$ such that

(8) $\quad \tau_{t, i} w_{t, i} L_{t, i}=\sum_{j=j r+1}^{J} p_{t, j, i} N_{t, j, i}=\rho_{t, i} w_{t, i}\left(1-\tau_{t, i}\right) \sum_{j=j r+1}^{J} N_{t, j, i}$,

where $\rho_{t, i}$ denotes the net replacement rate and $\tau_{t, i}$ the contribution rate of the pension system in $t, i$. Households consider the contributions as pure taxes.

The main policy parameter is the net replacement rate $\rho$; the contribution rate $\tau$ responds passively to balance the pension system's budget. If $\rho$ is large, public pensions crowd out private saving through the households consumption/saving decision given by (5) and (6). Moreover, since the benefits are not related to individual earnings, we consider the contributions to the pension system as pure taxes with the associated labor supply distortions which work through the households labor supply decision given by (5), (6) and (7).

If $\rho=0$, all old age provision will be private savings. This represents the textbook life-cycle model in which intertemporal consumption smoothing over the life cycle provides the retirement income through saving in young age and dissaving after retirement.

Pension reform is modeled as a reduction of the net replacement rate $\rho$. We will consider two polar cases:

- FLATSS: maintaining the current country-specific replacement rates also in the future $\left(\rho_{t, i}=\rho_{2005, i}\right.$ for $\left.t>2005\right)$, and

- SAVING: abolishing the public pension system altogether $\left(\rho_{t, i}=0\right)$ so that all age provision is private savings 


\subsection{Equilibrium}

Given initial capital stocks $K_{0, i}$, a competitive equilibrium of the economy is defined as sequences of disaggregate variables for the households, $\left\{c_{t, j, i}, l_{t, j, i}, h_{t, j, i}, a_{t, j, i}\right\}$, sequences of aggregate variables, $\left\{C_{t, i}, L_{t, i}, K_{t, i}\right\}$, prices for labor as well as contribution rates to the pension system, $\left\{w_{t, i}, \tau_{t, i}\right\}$, in each country $i$, and a common world interest rate $\left\{r_{t}\right\}$ such that

1. Given prices and initial conditions, households maximize life-time utility in (5) subject to the constraints in (6) and (7).

2. Factor prices equal their marginal productivities as given in equations (3) and (4).

3. Government policies satisfy (8) in every period.

4. All markets clear in all $t, i$.

$$
\begin{aligned}
& L_{t, i}=\sum_{j=0}^{J} \varepsilon_{j} l_{t, j, i} h_{t, j, i} N_{t, j, i} \text { for all } t, i \\
& \sum_{i=1}^{I} K_{t+1, i}=\sum_{i=1}^{I} \sum_{j=0}^{J} a_{t+1, j+1, i} N_{t, j, i} \\
& \sum_{i=1}^{I} \sum_{j=0}^{J} c_{t, j, i} N_{t, j, i}+\sum_{i=1}^{I} K_{t+1, i}=\sum_{i=1}^{I} \Omega_{t, i} K_{t, i}^{\alpha} L_{t, i}^{1-\alpha}-(1-\delta) \sum_{i=1}^{I} K_{t, i} .
\end{aligned}
$$

\subsection{Numerical implementation}

Our time line has four periods: a phase-in period, a calibration period, a projection period, and a phase-out period. First, we start calculations 110 years before the calibration period begins with the assumption of an "artificial" initial steady state in 1850 . The time period between 1960 and 2004 is then used as calibration period in order to determine the structural parameters of the model. Our projections run from 2005 through $2100 .{ }^{4}$ The phase-out period after 2100 has two parts: a transition to a steady-state population in 2200 and an additional 100year period until the macroeconomic model reaches a final steady state in 2300 .

\footnotetext{
${ }^{4}$ Results are displayed through the year 2050 to show the main period of population aging.
} 
We determine the equilibrium path of the overlapping generations model by using the modified Gauss-Seidel iteration as described in Ludwig (2006). The algorithm searches for equilibrium paths of capital to output ratios, and, in case there are social security systems, pension contribution rates in each country.

\subsection{Calibration}

The current version of the paper features a calibration that is based on an ad hoc choice of parameters by reference to other studies. In future versions of the paper we will specify certain calibration targets and determine deep structural model parameters by minimum distance methods. In particular, we will emphasize a careful calibration of the consumption weight in the utility function, $\varphi$, that determines the relative preference for labor versus leisure and thereby indirectly the number of households at the constraint with $h_{j}=1$. We currently set $\varphi=0.66$ which corresponds with the value determined by minimum distance methods in Börsch-Supan, Ludwig and Winter (2006).

The structural model parameters are summarized in table 2. These parameter values refer to an annual periodicity of the model.

TABLE 2: Structural model parameters

\begin{tabular}{ll}
\hline \hline$\alpha$ : capital share in production & 0.4 \\
$g$ : growth rate of labor productivity & 0.015 \\
$\delta$ : depreciation rate of capital & 0.05 \\
$\Omega_{i}$ : technology level & $0.05-0.07$ \\
$\beta$ : discount factor & 0.99 \\
$\theta:$ coefficient of relative risk aversion & 2 \\
$\varphi:$ consumption share parameter & 0.66 \\
\hline \hline
\end{tabular}




\section{Results}

We structure our results by investigating three dimensions, each with two polar assumptions:

- Labor market reforms: no reform at all, resulting in future labor force participation rates that equal the current ones (STATQUO or SQ) versus the implementation of all four reform steps described in section 3 (LREFORM or RF)

- Pension reform: a prototypical pension system of Continental Europe, purely pay-as-yougo, providing flat social security benefits financed by distorting contributions (FLATSS or FL) versus a fully-funded, voluntary private accounts system which generates no distortions (SAVING or SA) as described in subsection 4.5 .

- Labor supply reaction: Fixed hours supply (EXOGENOUS or EX) versus endogenous supply of working hours (ENDOGENOUS or EN) as described in the households optimization problem, subsection 4.3, equations (5) to (7).

This set-up yields a two-by-two-by-two table of underlying assumptions displayed in table 3. The eight resulting combinations are labeled, e.g., by "FL-SQ-EX" to denote a flat benefit pay-as-you-go social security system (FL) with status quo labor force participation (SQ) and an exogenously given hours supply (EX), by "SV-RF-EN" to denote a fully-funded private savings based old-age provision system (SV) with a comprehensive labor market reform (RF) and an hours supply which reacts endogenously to ageing and policy changes (EN), etc.

TABLE 3: Set up of scenarios

\begin{tabular}{|c|c|c|c|c|}
\hline & \multicolumn{4}{|c|}{ Extensive margin: Labor market regime } \\
\hline & $\begin{array}{c}\text { Constant age and gender specific } \\
\text { labor force participation } \\
\text { (STATQUO, blue diamonds) }\end{array}$ & $\begin{array}{c}\text { Increasing age and gender specific } \\
\text { labor force participation } \\
\text { (LREFORM, red triangles) }\end{array}$ \\
\hline Pension system & $\begin{array}{c}\text { EXOGENOUS } \\
\text { hours supply } \\
\text { (dashed line) }\end{array}$ & $\begin{array}{c}\text { ENDOGENOUS } \\
\text { hours supply } \\
\text { (solid line) }\end{array}$ & $\begin{array}{c}\text { EXOGENOUS } \\
\text { hours supply } \\
\text { (dashed line) }\end{array}$ & $\begin{array}{c}\text { ENDOGENOUS } \\
\text { hours supply } \\
\text { (solid line) }\end{array}$ \\
\hline $\begin{array}{c}\text { Pay-as-you-go with } \\
\text { flat benefits } \\
\text { (FLATSS, blue line) }\end{array}$ & $\boldsymbol{F L - S Q - E X}$ & $\boldsymbol{F L - S Q - E N}$ & $\boldsymbol{F L}$ - RF-EX & $\boldsymbol{F L - R F - E N ~}$ \\
\hline $\begin{array}{c}\text { Fully funded voluntary } \\
\text { accounts } \\
\text { (SAVING, yellow line) }\end{array}$ & $\boldsymbol{S V - S Q - E X}$ & $\boldsymbol{S V - S Q - E N}$ & $\boldsymbol{S V - R F - E X}$ & $\boldsymbol{S V - R F - E N}$ \\
\hline
\end{tabular}


On the following pages, we develop how the outcome variables of our general equilibrium model emerge from the three exogenous changes that drive our model:

- the demographic aging process in the background,

- lifting of labor supply restrictions as described in section 3, and

- a fundamental change in the type of pension system.

We begin with figures that display the evolution of employment, the supply of hours, total labor supply, wages, and domestic capital stock. We then present the evolution of our two target variables, GDP and consumption per capita.

All figures refer to the aggregate of France, Germany, and Italy (EU-3). The U.S. is modeled in the background with similar changes in retirement age and female labor force participation, but no other exogenous policy changes.

All figures have the same design (cf. table 3). We denote exogenous labor supply by a dashed line and endogenous hours' supply by a solid line. The high labor force participation scenario (LREFORM) is marked by red triangles, the constant labor force participation scenario (STATQUO) by blue diamonds. Finally, the flat benefits pay-as-you-go social security system (FLATSS) features a blue line, while the fully funded pension regime (SAVING) is identified by a yellow line. The first diagram in each figure shows all eight combinations of the scenarios. The following three smaller panels show the differences in each of the three directions in order to identify interaction effects. 


\subsection{Extensive margin: Employment}

Figure 8 corresponds to figure 6 in section 3 and depicts the evolution of labor supply at the extensive margin, i.e. the exogenously given number of persons who participate in the labor market: $\mathrm{L}_{\mathrm{t}, \mathrm{i}}=\sum_{\mathrm{j}=0}^{\mathrm{J}} \mathrm{l}_{\mathrm{t}, \mathrm{j}, \mathrm{i}} \mathrm{N}_{\mathrm{t}, \mathrm{j}, \mathrm{i}}$.

FIGURE 8: Employment, indexed to 2005=100\%, EU-3

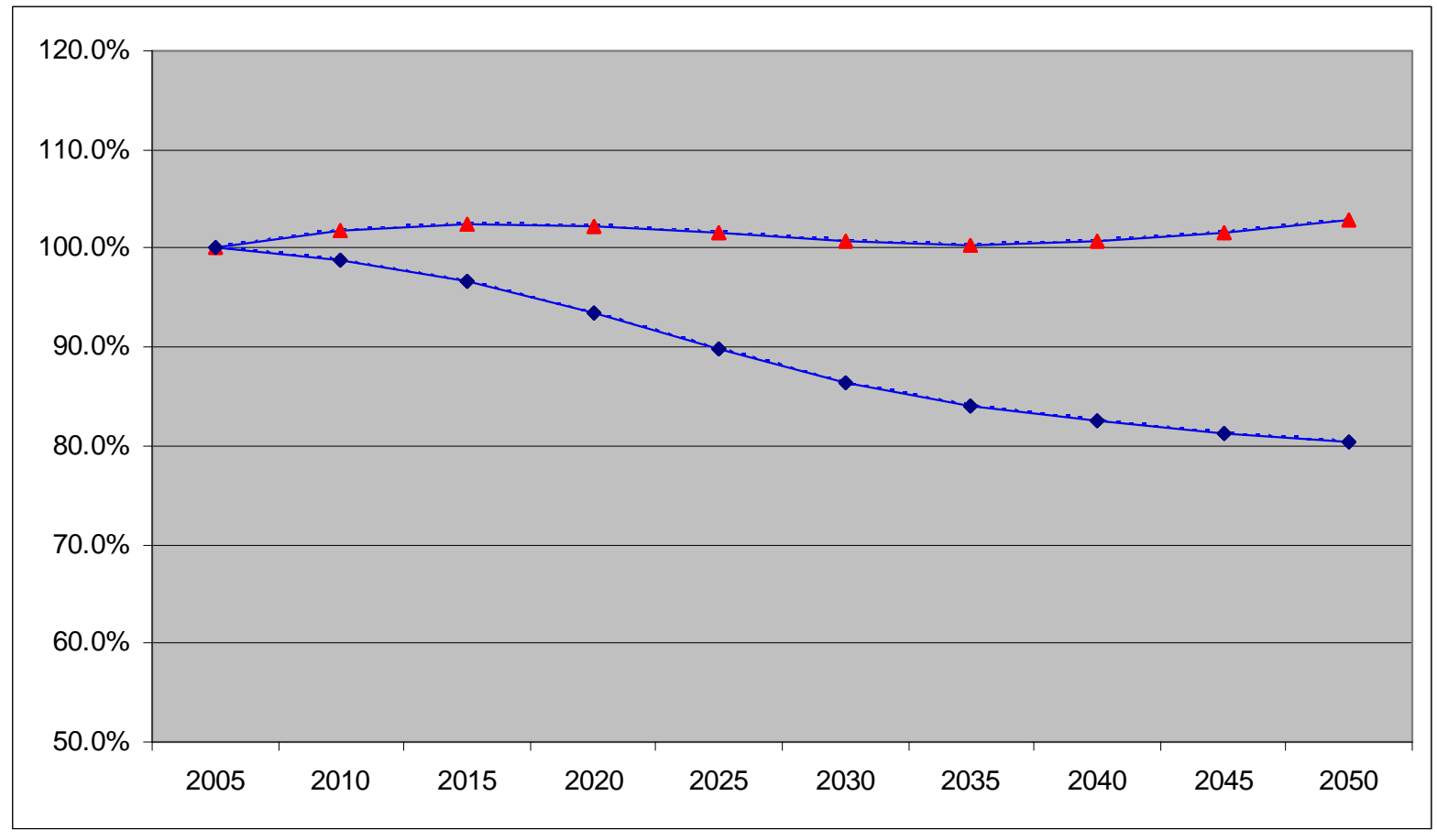

The STATQUO scenario is marked by blue diamonds. It shows a steady decline of the number of employed persons. The decline is about 20\% between 2005 and 2050.

This is very different from the LREFORM scenario (marked by red triangles). The increase in labor force participation due to all four reform steps - earlier entry in, and later exit from, the labor market, more women working and less unemployed - more or less stabilizes employment in the EU-3 area. Labor supply declines only slightly after 2015 but increases again after 2035, the peak of the ageing process in Continental Europe. Except for the time between 2015 and 2035, when the losses in employment created by the retirement of the babyboom generation are very large, the effects of labor market reforms and migration just compensate the aging effects. 


\subsection{Intensive margin: the supply of hours for given labor force participation}

The supply of working hours now reacts to the exogenous change in labor force participation according to the household's maximization problem as specified in subsection 4.3. We distinguish two cases: households which are constrained by the time endowment limit (equation 7 in section 4.3), and households which are not constrained.

Given the calibration parameters, about 58\% of households are not constrained in 2005, mainly middle aged households. The difference between France and Germany on one side, and Italy on the other side, is large: in France, $67 \%$ of all households are unconstrained, in Germany 63\%, while only $43 \%$ of Italian households can work as much as they would like. These households fully undo exogenous policy changes by adjusting their working hours inversely, since for them hours $h$ and persons $l$ are perfect substitutes (equations 5 and 6 in section 4.3). One might think of these households as a couple. In the status-quo regime, one person was restricted to work while the other person worked as much as the household needed for consumption and saving. Once the restriction for the first person was lifted, however, the couple distributes the work more equally between the two persons without increasing total hours supplied by the household.

Figure 9 shows this from a microeconomic perspective, i.e., on the level of an individual representative households of each age class, separately for each country. For unconstrained households (hours less than one), the hours (marked by red squares) respond inversely to the changes in participation (blue diamonds) when moving from the status quo (left panels) to the LREFORM regime (right panels).

The remaining $42 \%$ of households have been constrained under the labor market policy regimes in 2005. This is the majority in Italy, where $57 \%$ of all households are constrained, and roughly a third in France (33\%) and Germany (37\%). These households are shown in figure 9 as those households which have an hours supply of exactly one: the very young and the old. Releasing these constraints generates more hours supply when the policies are phased in over time. This is visible in the lower number of households on the hours=1 line in the LREFORM scenarios (right panels) than under STATQUO labor force participation (left panels).

Taking both participation and hours together yields total labor supply of the household (marked by yellow triangles in figure 9). It is much higher for the younger and older age groups in the LREFORM scenario as compared to the STATQUO scenario, but remains un- 
changed for the unconstrained middle aged households which perfectly substitute between participation and hours supply.

FIGURE 9: Household labor force participation, hours supply and total labor supply

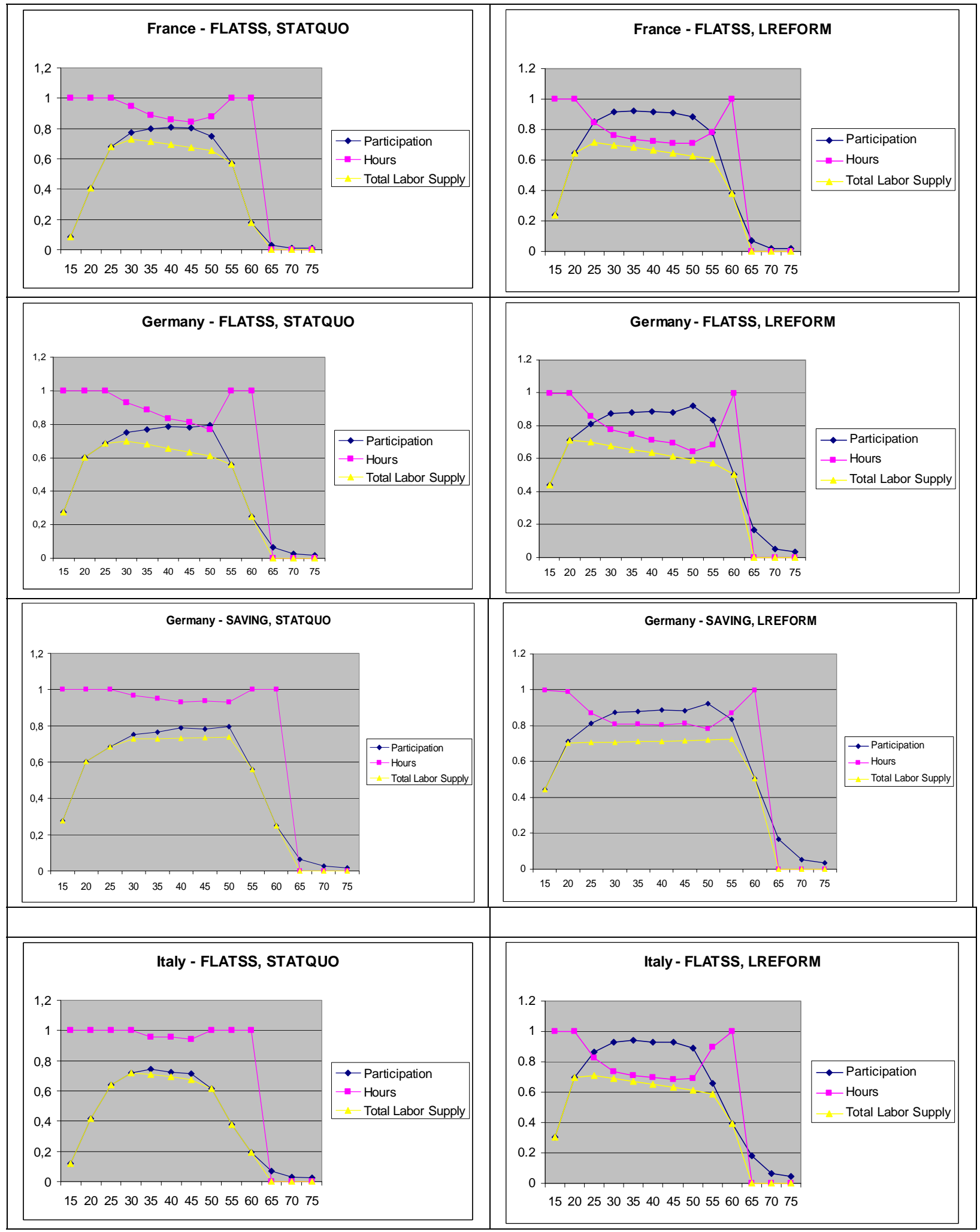


Figure 10 turns to the macroeconomic view. It shows the aggregate supply of working hours: $\mathrm{H}_{\mathrm{t}, \mathrm{i}}=\sum_{\mathrm{j}=0}^{\mathrm{J}} \mathrm{h}_{\mathrm{t}, \mathrm{j}, \mathrm{i}} \mathrm{N}_{\mathrm{t}, \mathrm{j}, \mathrm{i}}$ for a labor force participation of one in all working age households (age 20-64). Hours are normalized to 100\% in 2005 within each scenario. Hence, they are adjusted for any level effects generated by pension and labor market policies that create cross-country differences already in 2005.

Figure 10 shows the hours result for the eight scenarios defined in table 3. Population aging generates declining hours in all scenarios. There is, of course, no difference among the four scenarios with exogenous hours supply as this is fixed to one. It can be interpreted as the baseline which reflects the decline in working age population without any reaction in supplied working hours.

The reaction of the endogenous hours' supply differs by labor market and pension scenario. Hours are much lower in the LREFORM scenarios (red triangles) than under constant labor force participation rates (STATQUO, blue diamonds).

There are interesting interaction effects between labor market and pension reform. Without labor market reform, hours' supply is almost identical in the FLATSS and SAVING pension scenarios; actually, hours supplied are a bit lower in the pension reform scenario. This relation reverts when the labor reforms are put in place. If labor market and pension reform concur, hours' supply is higher than in the case when labor markets are reformed without a pension reform.

A microeconomic perspective of this interaction effect is given in figure 9 for the case of Germany. A comparison between the second and the third left panels shows that the hours reduction is much smaller in a funded pension system than in a flat-benefits pay-as-you-go system. This reflects the negative incentive effect of high distorting taxes. Under the LREFORM scenario (right panels) fewer households are constrained by labor market institutions. More age groups therefore substitute hours for participation within a household. Since the hours reduction is much smaller in the funded pension system, more total labor supply remains. 
FIGURE 10: Hours for fixed labor force participation, indexed to $2005=100 \%, E U-3$
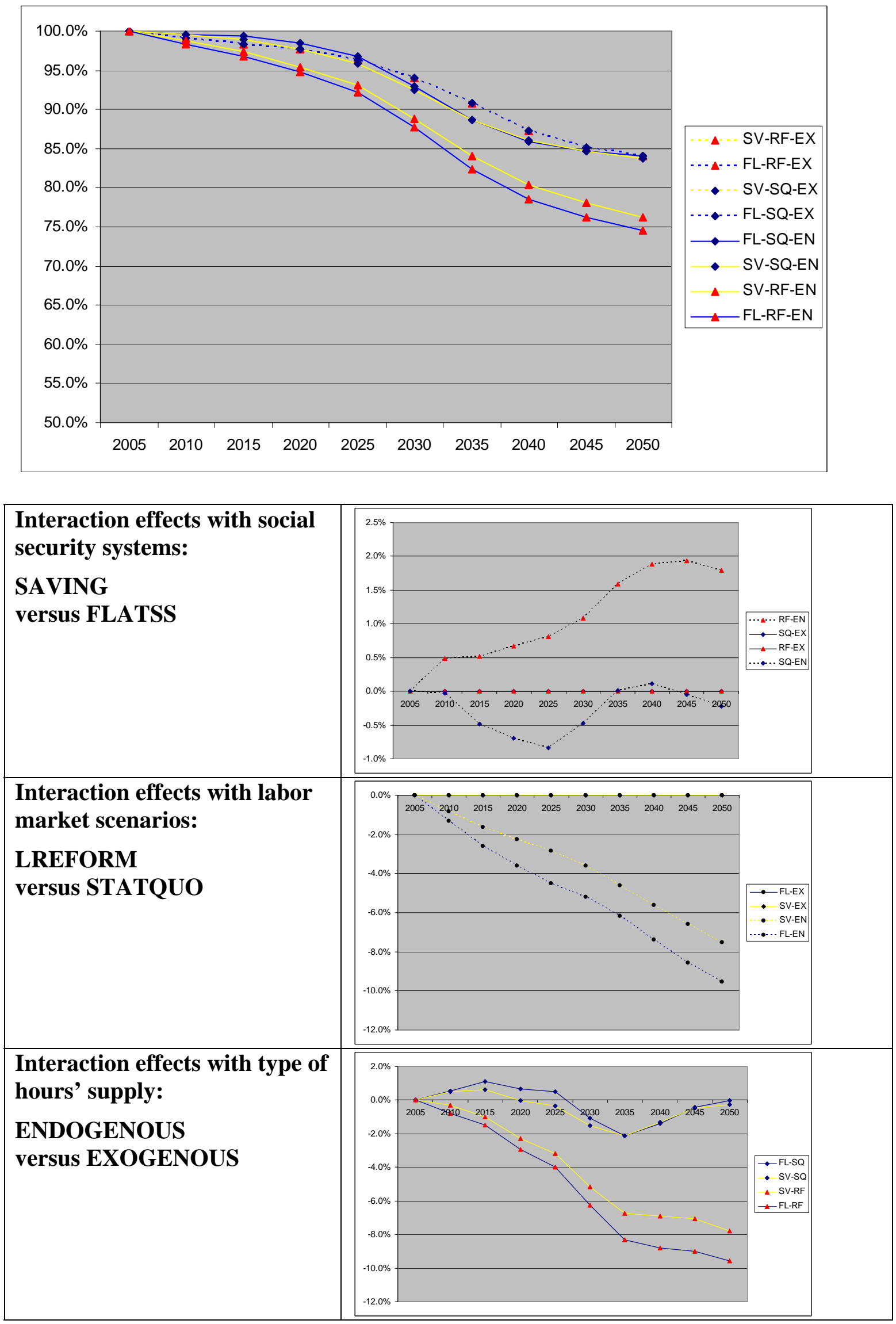
Another way to understand the interaction effects is taking first differences in the direction of each dimension of the two-by-two-by-two table 3. This is done in the three smaller panels of figure 10 labeled "interaction effects". The first panel shows the impact of a radical social security reform. Hours increase under a funded system via-a-vis the pay-as-go system if exogenous labor force participation also increases. The difference is zero if hours are exogenous, and very small, but negative if labor force participation remains at status quo.

The second panel displays the difference between higher and unchanged exogenous labor force participation. Hours react negatively because of intra-household substitution between hours and labor force participation. This effect offsets some, but not all of the higher labor force participation as we will see in the following subsection. The offsetting effect is higher in a distorting pay-as-you-go system. We may interpret the additional difference between the two lines in the second interaction effect as an incentive effect due to distorting taxes, while the difference between the horizontal axis and the yellow line is the substitution effect between hours and labor force participation.

The third panel summarizes these effects as it displays the difference between endogenous and exogenous hours' supply under the four combinations of pension and labor market regimes while the two former graphs can be interpreted as differences in differences. Quite clearly, there is a strong and beneficial interaction between changing the pension system and lifting labor market restrictions. This is an important result of our paper.

\subsection{Putting all together: total effective labor supply}

Total labor effective supply is the product of working persons (figure 8) and hours per person (figure 10), adjusted for age-specific productivity: $L_{t, i}=\sum_{j=0}^{J} \varepsilon_{j} l_{t, j, i} h_{t, j, i} N_{t, j, i} \cdot{ }^{5}$

Its evolution under the eight scenarios is displayed in figure 11. If hours are exogenous, there is no difference between figures 8 and 11, and there is no difference between the two pension scenarios. Hence, the lines for FL-RF-EX and SV-RF-EX at the very top overlap as well as the lines representing FL-SQ-EX and SV-SQ-EX at the very bottom. This is also visible in the first panel on interaction effects.

\footnotetext{
${ }^{5}$ See section 6 . All graphs in section 4 are based on a flat age-productivity profile $\left(\varepsilon_{j}=1\right)$. Aggregate results are not sensitive to the age-productivity profile.
} 
If hours are endogenous, the increase in the number of working persons in the LREFORM scenario is only partially reduced by the decline in hour's supply that we have seen in figure 10. Figure 11 is the aggregate picture representing the total labor supply of the various age groups depicted in figure 9 (yellow triangles).

The first panel on interaction effects shows again the strong interaction between pension reform and labor market reform: relative to the current pay-as-you-go system, total labor supply increase strongly after 2020 in the LREFORM scenario, while it declines if labor force participation remains unchanged. 
FIGURE 11: Total labor supply, indexed to $2005=100 \%$, EU-3
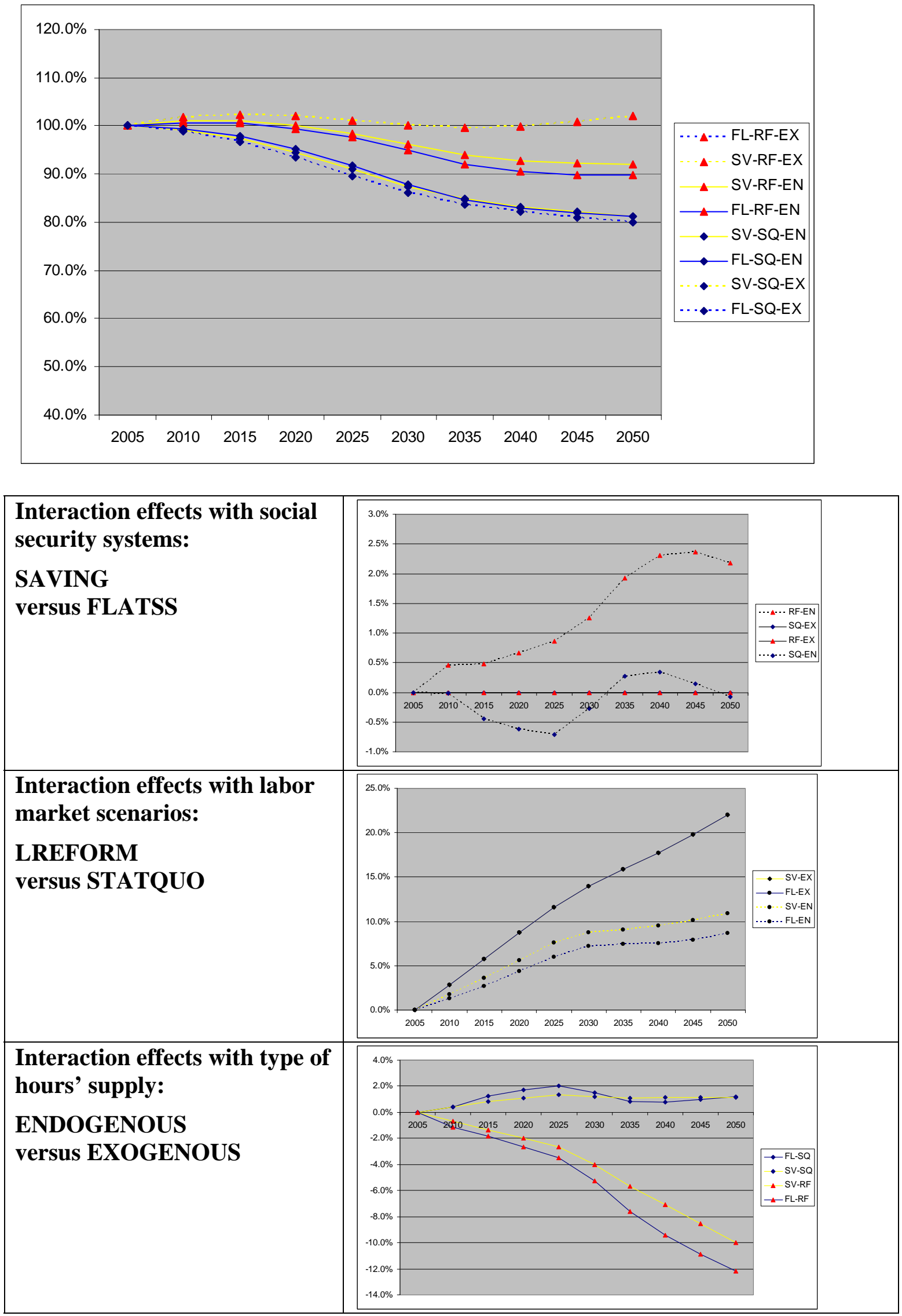


\subsection{Hourly wage rate}

The hourly wage rate is depicted in Figure 12. It more or less reflects the supply of total effective labor with some additional effects due to capital accumulation, see the following subsection.

The hourly wage increases more in the STATUSQUO (blue diamonds) than in the LREFORM (red triangles) scenario, reflecting relative scarcity. It increases much stronger under a funded system (yellow lines) than under pay-as-you-go (blue lines). The additional capital accumulation lowers interests and raises labor productivity, thus also the wage rate. Finally, the wage rate increase more when hours are exogenous (dashed lines). This effect is very small when labor force participation rates do not change (STATQUO) but it is substantial in the LREFORM scenario, when the hours' reaction is large.

Considering the massive decline in total labor supply, the hourly wage rate reacts somewhat dampened with an elasticity of about 0.5 (compare figures 11 and 12). 
FIGURE 12: Hourly wage rate, indexed to $2005=100 \%, E U-3$
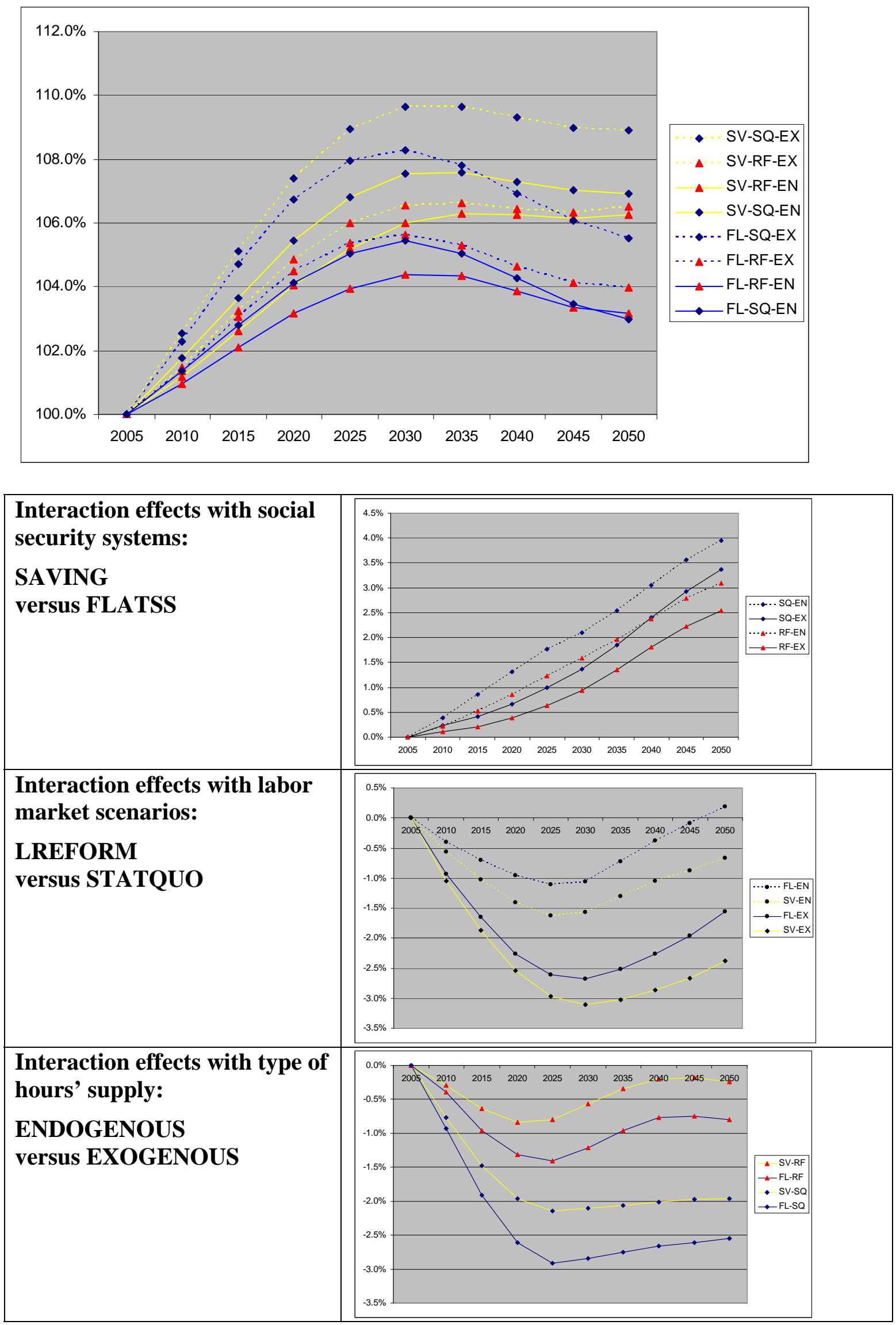


\subsection{Capital accumulation}

Figure 13 depicts the evolution of the combined domestic capital stock of France, Germany, and Italy. As expected, capital accumulation is much higher under a funded pension system than in a pay-as-you-go system as can be seen in the first panel of interactions. There is also substantially more capital accumulation in the high labor force participation scenario (LREFORM) as compared to constant participation (STATQUO). This is visible in the second panel on interaction effects. Finally, the third panel shows that capital accumulation is higher if endogenous hours' supply is not dampening the effect of a higher labor force participation.

Combining these three effects yields the top diagram of figure 13. Capital accumulation is highest under a fully-funded system with high labor force participation and no dampening effect of endogenous hours (SV-RF-EX). It is lowest in a pay-as-you-go system with statusquo labor force participation and the full force of negative incentive effects (FL-SQ-EN). 
FIGURE 13: Domestic capital stock, indexed to 2005=100\%, EU-3
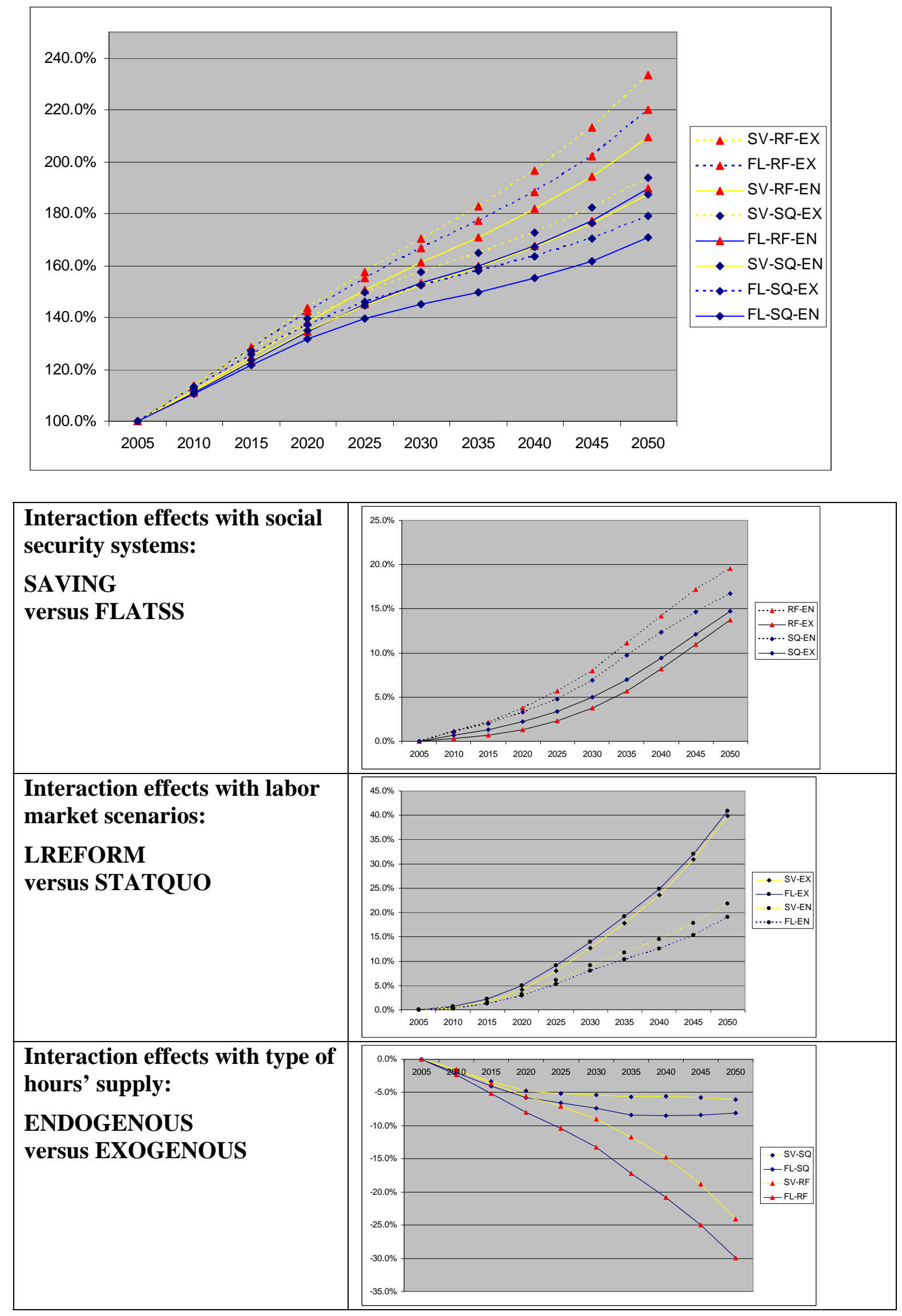


\subsection{GDP per capita}

Our first target variable is economic growth, measured as the change in GDP per capita, net of exogenous growth in total factor productivity. This is displayed in figure 14. Economic growth relative to secular productivity growth is very much affected by the combination of pension and labor market policies. With exogenous hours, growth is highest and always positive when labor supply restrictions are released and pensions are financed by a funded system. In turn, growth (after adjusting for TFP increases) is lowest and always negative under the opposite combination of policies. This is a strong message: in spite of aging, economic growth can be as high as historically given by the estimated long-run growth of total factor productivity. It can even be increased by a smart combination of pension and labor market policies. However, it can also secularly decline behind the path which we have experienced in the past.

The quantities are large: the difference between the best and the worst scenario is about $20 \%$ in 2040 and 30\% in 2050. This must be seen in comparison to total factor productivity growth which is about $90 \%$ over the period from 2005 to 2050, almost doubling output. ${ }^{6}$ Remaining at status quo in terms of labor market and pension policy will "eat up” about a third of productivity growth. Reform backlash is about half of this: it reduces the effect of labor market reform on GDP per capita to about half the size with unchanged hours’ supply.

The eight output paths in figure 14 can be derived as a straightforward combination of labor and capital inputs displayed in figures 11 and 13. Output per capita is unequivocally higher in a fully-funded pension system without distorting taxes as compared to a pay-as-you-go pension system with flat benefits. Output per capita is similarly clearly higher when labor market restrictions are removed (LREFORM) than in the status-quo scenario. The latter two findings are clearly seen in the first two small panels below the large diagram.

The third panel shows the interaction between pension and labor market policies in the case of endogenous supply of working hours. Endogenous hours' supply reduces growth relative to a situation when households cannot substitute more persons by less hours. This is shown by the two lines at the bottom of this graph (FL-RF and SV-RF). The effect, however, is smaller when the pension system is fully funded (SV-RF).

\footnotetext{
6 The growth path with this productivity increase, without population aging and reform effects, ist represented by the horizontal 100\%-line in figure 14 .
} 
FIGURE 14: GDP per capita, indexed to 2005=100\%, EU-3
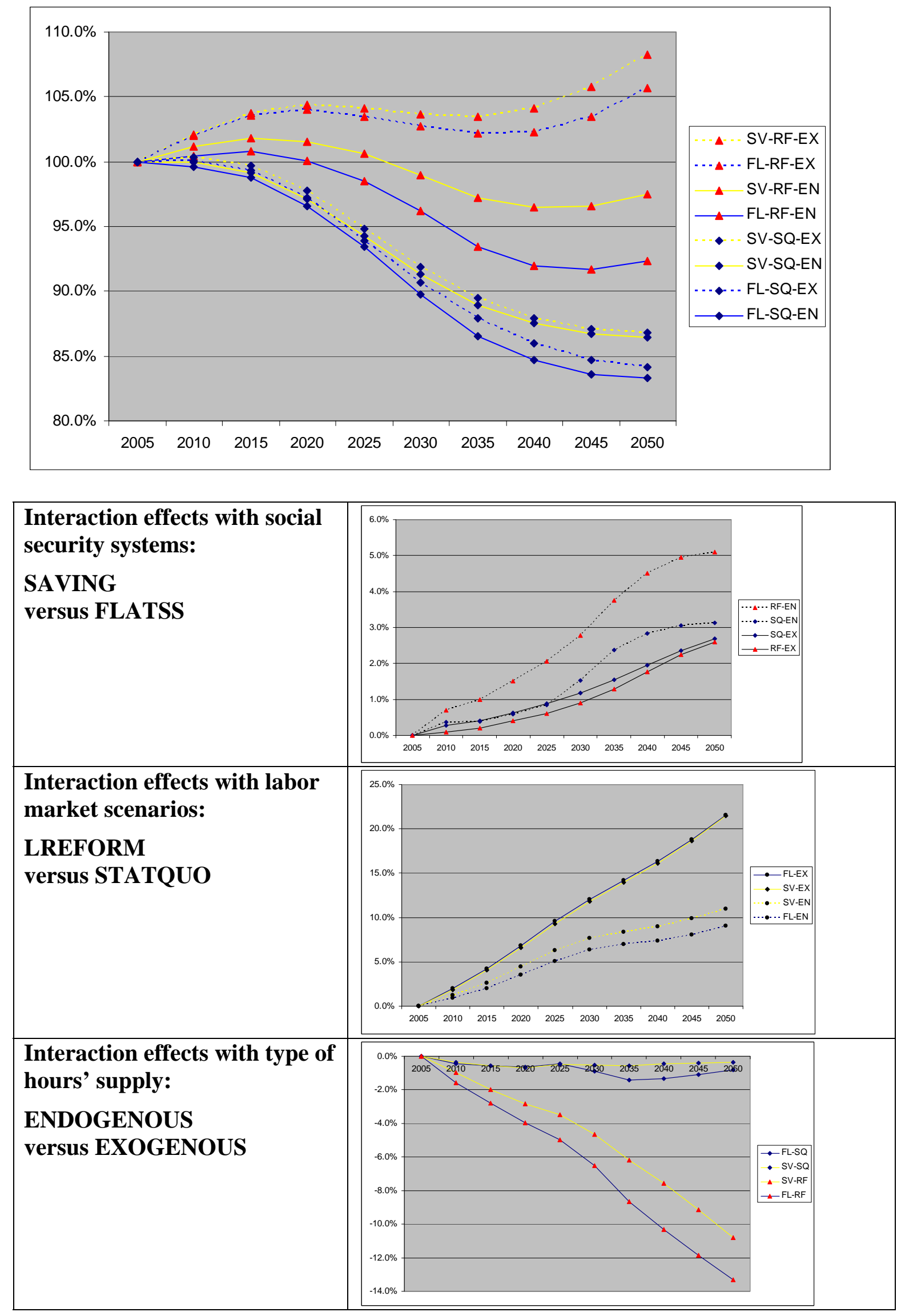


\subsection{Consumption per capita}

Finally, figure 15 displays our second target variable, living standards measured by consumption per capita. As we did it for output, we normalize consumption per capita by secular total productivity growth. The evolution of living standards very much parallels that of GDP per capita; there are no major deviations in the growth patterns of output and consumption as it concerns the relative position of the eight scenarios.

Saving in young age and dissaving in old age, however, smoothes some of the effects that we have seen in figure 14. A notable example is the evolution of living standards in the fullyfunded pensions, high labor force participation, and endogenous hours' supply scenario (SVRF-EN). Living standards remain very close to the secular growth path (the horizontal line), while the associated GDP per capita exhibited a stronger increase until 2020 followed by a strong decline.

This shows that a smart combination of labor market and pension policies can stabilize living standards in Continental Europe in spite of population aging and an adverse behavioral reaction to the structural policy changes. In turn, this stabilization needs more than a half-hearted pension reform or a few adjustments in labor market restrictions. All labor market policies described in section 3 are needed in addition to a secular pension reform; other policy scenarios imply that living standards in Continental Europe will grow slower than what we have experienced in the past. Living standards will not decline because secular productivity growth is still stronger than aging. Living standards, however, will decline relative to all other countries that age less than Continental Europe. 
FIGURE 15: Consumption per capita, indexed to 2005=100\%, EU-3
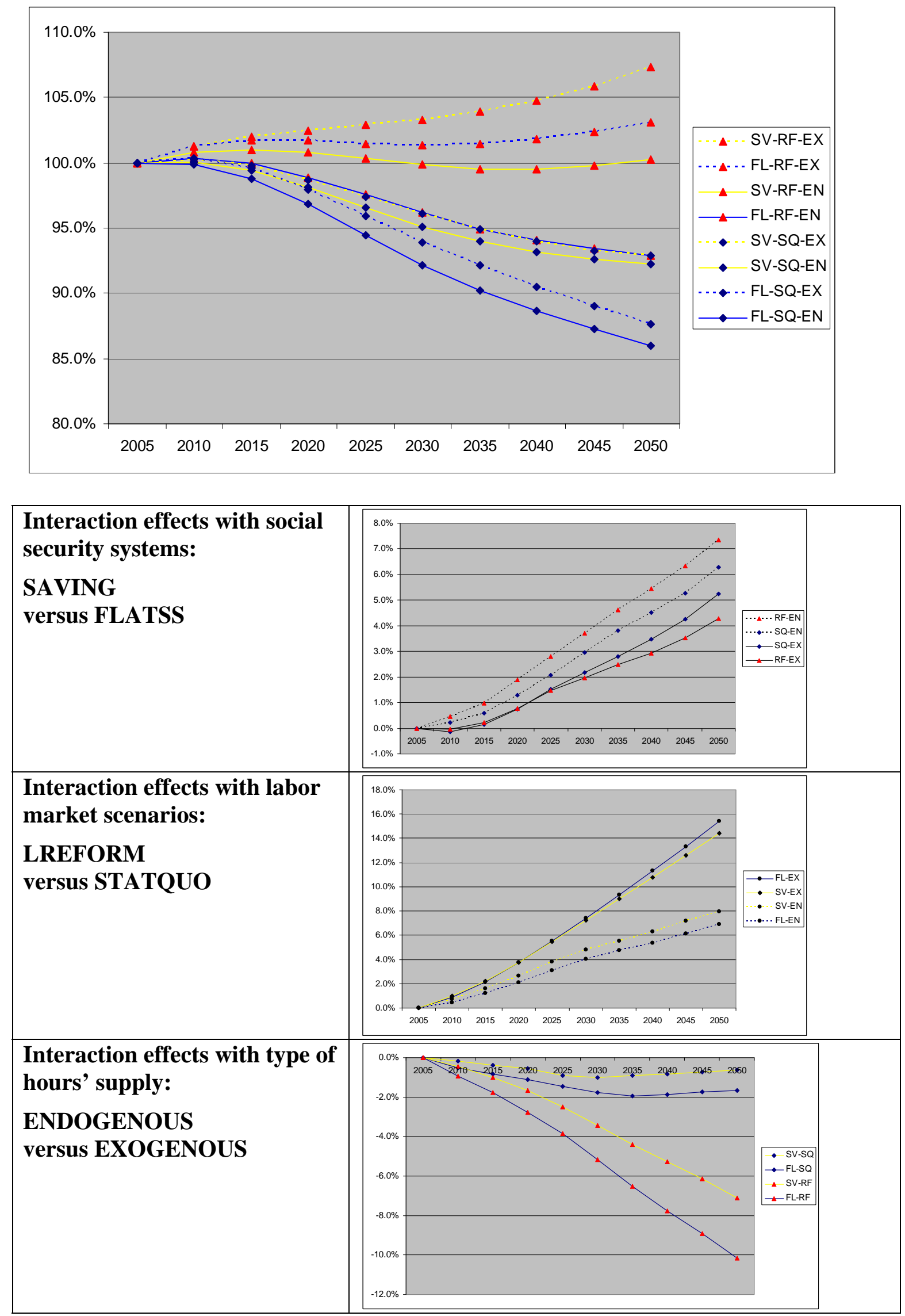


\section{Productivity issues}

If labor productivity is age dependent, a shift in the age structure will also bring about a change in aggregate productivity, even if age-specific productivity were to remain constant. Moreover, if labor productivity declines strongly after, say, age 60, an increase in retirement age will not have much effect on aggregate output. This brief section provides a gross estimate of the approximate magnitude of this effect.

This is not a simple task, however, as there is no reliable data available on age-specific labor productivity, see the review by Skirbekk (2004). Barth et al. (1993) conclude from a survey of human resource executives in 406 organizations that "Older workers were consistently rated as having more positive attitudes being more reliable and possessing better skills than the average worker; they were rated worse than the average worker when it comes to health care costs, flexibility in accepting new assignments, and suitability for training.” Hutchins (2001) questions the usefulness of such employer survey to address these issues because of justification bias. Kotlikoff and Wise (1989) evaluate confidential data originating from a major US American service enterprise in which output is well defined. They provide two estimates which can be used to proxy productivity. One measure uses age and seniority-specific earnings of sales staff which can be measured by the sale of insurance contracts, hence a kind of piece rate. Corrected for seniority, the age profile of these piece rates is relatively flat. Their second measure is the entry salary of clerks. This profile is much more hump shape. Both measures are likely to suffer from selection effects. Börsch-Supan, Düzgün and Weiss (2006) use another approach. They used confidential data on error rates in a large assembly line style car manufacturing factory. Output and production times are perfectly controllable in this environment, permitting a direct estimate of productivity. They find that age and experience effects cancel, such that the resulting productivity profile is essentially flat, with reliable observations until about age 63.

How do these microeconomic differences translate into macroeconomic differences? In order to get some feeling, we underlie our simulations with two alternative age-productivity profiles (in our model represented by $\varepsilon_{j}$, see subsection 4.3). One profile is flat; the other imposes the sharp hump shape depicted in figure 16. It features a strong decline of productivity after age 60 . We treat these age profiles as exogenous. 
FIGURE 16: Hump-shaped age productivity profile

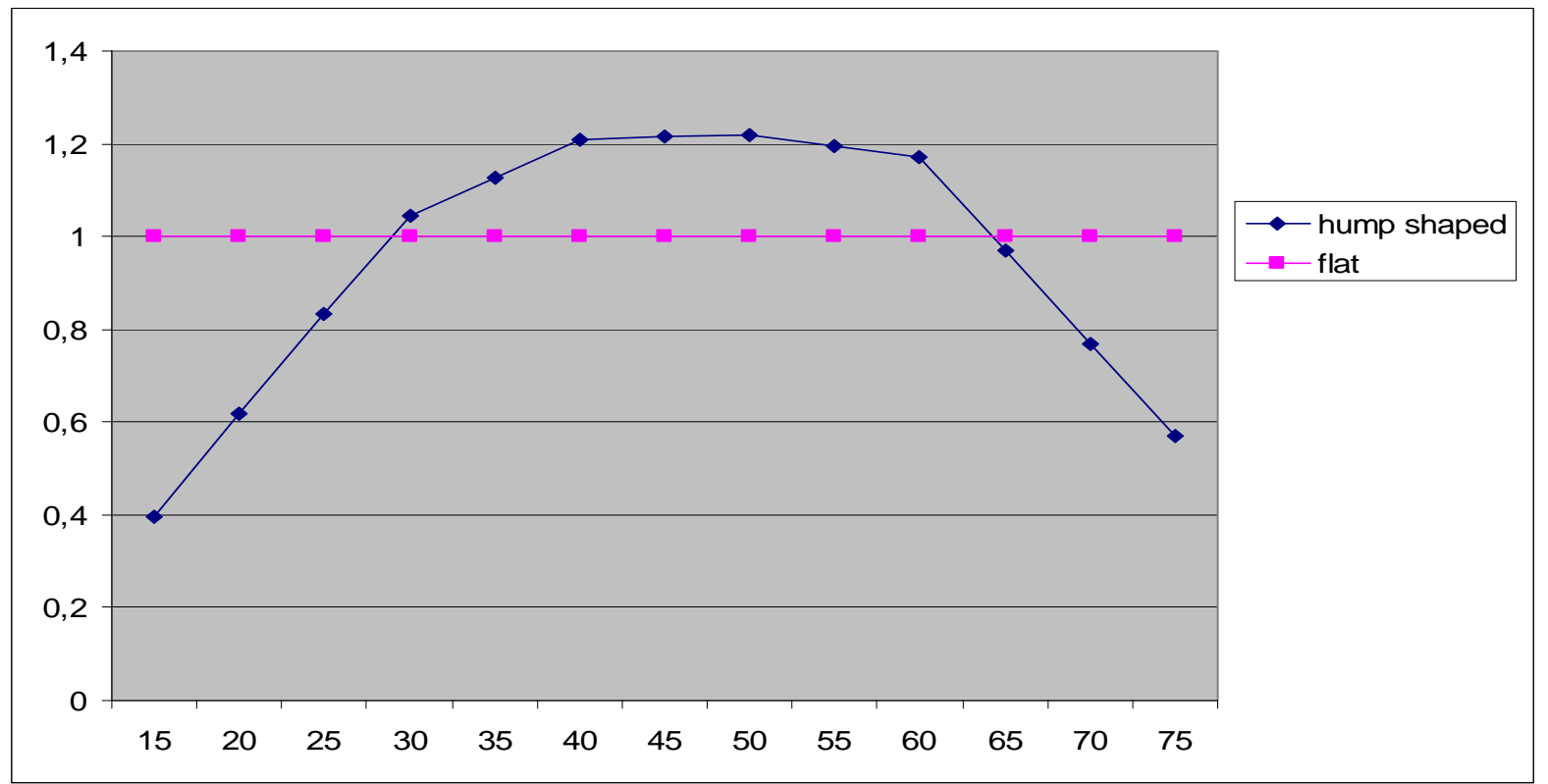

Figures 17 describes which difference it makes whether the age productivity profile is flat or whether it is hump-shaped. Figure 17 is computed under the assumptions of exogenous hours supply and the current pay-as-you-go system. We display the two extreme employment scenarios, STATQUO and LREFORM. In spite of the strong hump shape of figure 16, there is not much difference in the resulting GDP per capita, a result which may surprise.

FIGURE 17: GDP per capita, indexed to $2005=100 \%$, different productivity assumptions

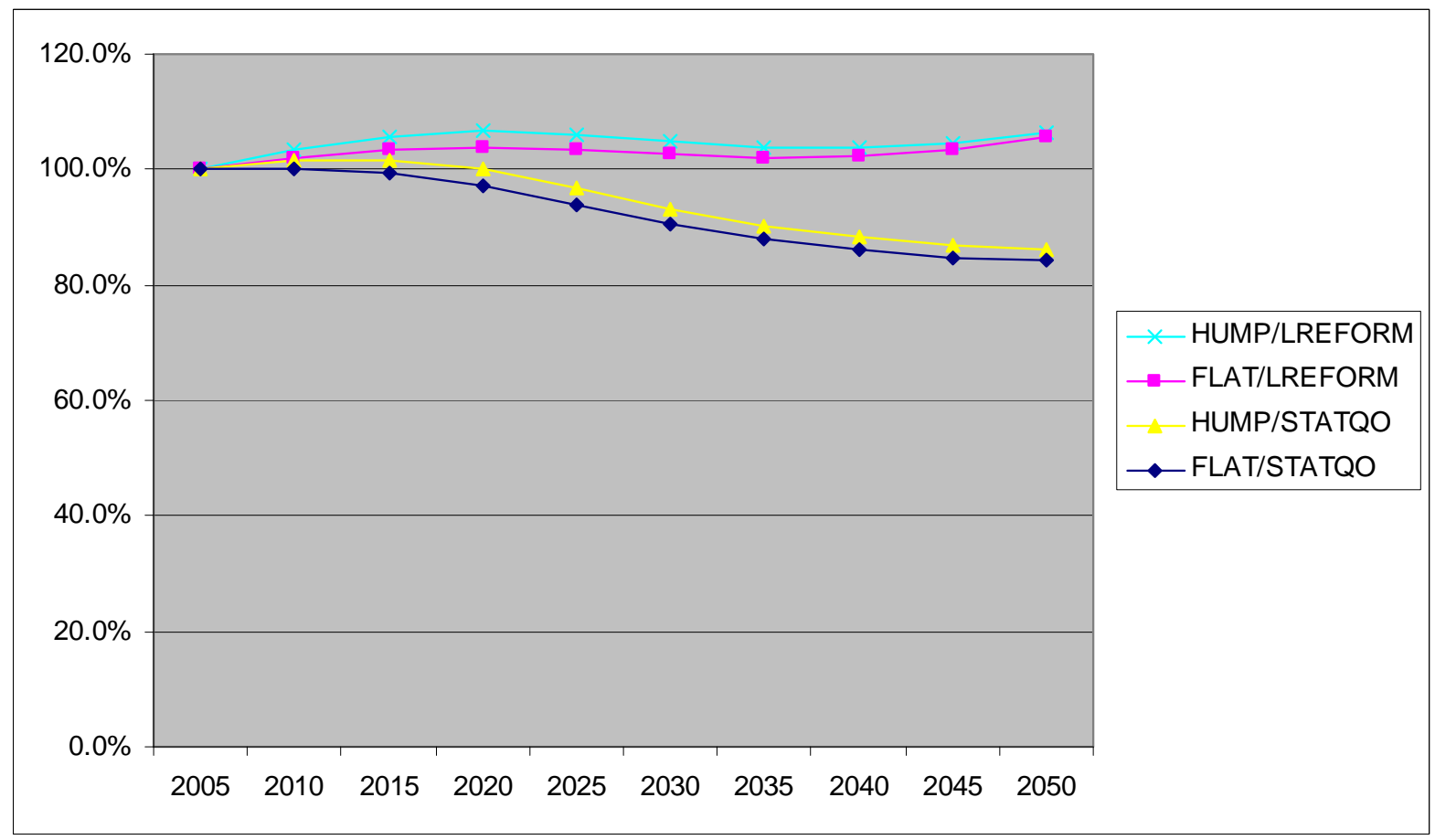




\section{Conclusions}

We have simulated a set of far-reaching pension and labor market policies and investigated their impact on production and consumption per capita in three large Continental European countries. A new feature of our computational general equilibrium model is a combination of exogenous changes of labor supply at the extensive margin (metaphorically represented in our model by the number of working persons) and endogenous responses of labor supply at the intensive margin (metaphorically called working hours). We think of exogenous changes as lifting institutional restrictions generated by the school system, actuarially unfair pension systems, inflexible working hours, and unavailable day care facilities. The endogenous component of labor supply ("hours" chosen by the household members) reacts to the exogenous component of labor supply (“working persons” freed from labor market restrictions), but also to social security taxes and to the aging process itself and its repercussions.

Our paper shows that direct quantity and indirect behavioral effects are large. They both significantly affect economic growth and living standards. Due to the strong interaction effects between pension system and labor markets, a smart combination of pension policy and adaptation of institutions related to the labor market can do more than such policies in isolation. We show that they could easily offset the effects of population aging on economic growth and living standards if there were no endogenous behavioral reactions. On balance, these behavioral effects dampen reform efforts, thus representing reform backlashes in our model. Taking behavioral effects into account, a combination of many policy measures is necessary in order to keep per capita consumption from falling behind the secular growth path. If these measures are taken, Old Europe can maintain her high living standards in spite of aging. This is an important message for the never ending reform debate on the European Continent.

The key of our approach - the combination of an exogenous variation of employment rates with endogenous hours choice - has its advantages and disadvantages. It provides a theoretically consistent way to model the subtle balance between policy changes and individual reactions. From an empirical point of view, this approach puts a lot of pressure to get the calibration right in order to achieve a realistic number of households that are constrained by labor market restrictions (expressed less metaphorically: the balance between what is exogenous and what is endogenous in labor supply). The current version of the paper features a calibration that is based on an ad hoc choice of parameters by reference to other studies. In future 
versions of the paper we will specify certain calibration targets and determine deep structural model parameters by minimum distance methods as we have done in earlier work.

From a theoretical point of view, we do not model a motive for households to actually participate in the labor market. An alternative approach making the metaphorical distinction more realistic would be to model the decisions endogenously at both margins. This could be done by accounting for home production and preferences for leisure goods as in Greenwood and Vandenbroucke (2005) and by explicitly modeling the institutions that determine households labor market participation decision, e.g., along the lines of Garibaldi and Wasmer (2005) and Guner, Kaygusuz and Ventura (2008). We speculate that removing these frictions would lead to stronger total labor supply reactions than in our model. Such extensions of our model are subject of future research.

\section{References}

Abel, A.B. (2001): Will bequests attenuate the predicted meltdown in stock prices when baby boomers retire? Review of Economics and Statistics, 83(4), 589-595.

Abel, A.B. (2003): The Effects of a Baby Boom on Stock Prices and Capital Accumulation in the Presence of Social Security, Econometrica, 71, 2, 551-578.

Altig, D., A.J. Auerbach, L.J. Kotlikoff, K.A. Smetters, and J. Walliser (2001): Simulating fundamental tax reform in the United States. American Economic Review, 91, 574595.

Ando, A. and F. Modigliani (1963): The 'life-cycle' hypothesis of saving: Aggregate implications and tests. American Economic Review, 89(3), 605-618.

Attanasio, O.P., Kitao, S. and G.L. Violante (2006): Quantifying the Effects of the Demographic Transition in Developing Economies, Advances in Macroeconomics, 6(1), Article 2. The B.E. Journals in Macroeconomics.

Attanasio, O.P., Kitao, S. and G.L. Violante (2007): Global Demographic Trends and Social Security Reform, Journal of Monetary Economics, 57(1), 144-198.

Auerbach, A.J. and L.J. Kotlikoff (1987): Dynamic Fiscal Policy. Cambridge, MA: Cambridge University Press.

Ball, L. and N. G. Mankiw (2002): The NAIRU in Theory and Practice, Journal of Economic Perspectives 16, 4, 115-136.

Barth et al (1993): "Corporations and the Aging Workforce.” Building the Competitive Workforce: Investing in Human Capital for Corporate Success, ed. Philip H. Mirvis: John Wiley \& Sons.

Bloom, D.E. and J.G. Williamson (1998): Demographic transitions and economic miracles in emerging Asia. World Bank Economic Review, 12(3), 419-455. 
Börsch-Supan, A., A. Ludwig, and J. Winter (2002): Aging, pension reform, and capital flows. In: A. Auerbach and H. Hermann (eds.), Aging, Financial Markets and Monetary Policy. Heidelberg: Springer, 55-83.

Börsch-Supan, A., A. Ludwig, and J. Winter (2006): Aging, Pension Reform, and Capital Flows: A Multi-Country Simulation Model, Economica, 73, 625-658.

Börsch-Supan, A., I. Düzgün and M. Weiss (2007), Productivity and the Age Composition of Work Teams: Evidence from the Assembly Line, MEA-Discussion Paper.

Börsch-Supan, A., J. Köke, and J. Winter (2004): Pension reform, savings behavior, and capital market performance. Journal of Pension Economics and Finance, forthcoming.

Brooks, R. (2002): Asset-market effects of the baby boom and social-security reform. American Economic Review, Papers and Proceedings, 92(2), 402-406.

Brooks, R. (2003): Population aging and global capital flows in a parallel universe. Working Paper No. 00/151, International Monetary Fund, Washington, D.C. Forthcoming in: IMF Staff Papers.

Buiter, W.H. (1981): Time preference and international lending and borrowing in an overlapping-generations model. Journal of Political Economy, 89(4), 769-797.

Cutler, D.M., J.M. Poterba, L.M. Sheiner, and L.H. Summers (1990): An aging society: Opportunity or challenge? Brookings Papers on Economic Activity, No. 1, 1-73.

Deardorff, A.V. (1985): Trade and capital mobility in a world of diverging populations. In: D.G. Johnson and R.D. Lee (eds.), Population Growth and Economic Development: Issues and Evidence. Madison, WI: University of Wisconsin Press.

Diamond, P.A. (1965): National debt in a neoclassical growth model. American Economic Review, 55, 1126-1150.

Domeij, D. and M. Floden (2006): Population Aging and International Capital Flows. International Economic Review, 47, 1013-1032.

Eurostat (2008): http://ec.europa.eu/eurostat/

Fehr, H., S. Jokisch, and L. Kotlikoff (2003): The developed world's demographic transition: The roles of capital flows, immigration, and policy. Working Paper No. 10096, National Bureau of Economic Research (NBER).

Fehr, H., S. Jokisch, and L. Kotlikoff (2004): The role of immigration in dealing with the developed world's demographic transition. Working Paper No. 10512, National Bureau of Economic Research (NBER).

Feroli, M. (2002): Capital flows among the G-7 Nations: a demographic perspective. Unpublished manuscript, New York University.

Guner, N., Kaygusuz, R. ad G. Ventura (2008): Taxation, Aggregates and the Household. Working Paper.

Hayashi, F. (1982): Tobin’s marginal q and average q: A neoclassical interpretation. Econometrica, 50, 213-224.

Henriksen, E. R. (2002): A demographic explanation of U.S. and Japanese current account behavior. Unpublished manuscript, Carnegie Mellon University.

Human Mortality Database (2008): http://www.mortality.org. 
Garibaldi, P. and E. Wasmer (2005): Equilibrium Search Unemployment, Endogenous Participation, and Labor Market Flows, Journal of the European Economic Association, 3(4), 851-882.

Greenwood, J. and G. Vandenbroucke, G (2005): Hours Worked: Long-Run Trends. Prepared for The New Palgrave Dictionary of Economics, 2nd edition, edited by Lawrence E. Blume and Steven N. Durlauf (London: Palgrave Macmillan).

Kotlikoff, L. and D. Wise (1989), Employee Retirement and a Firm's Pension Plan, in D.A. Wise, ed., The Economics of Aging, Chicago: University of Chicago Press, 279-334.

Krüger, D. and A. Ludwig (2007): On the Consequences of Demographic Change for Rates of Return to Capital, and the Distribution of Wealth and Welfare, Journal of Monetary Economics, 54(1), 49-87, 2007

Lazear, E. (1995), Personnel Economics, MIT-Press: Cambridge, Mass.

Lucas, R. E. (1988): On the mechanics of economic development. Journal of Monetary Economics, 22, 3-42.

Ludwig, A. (2004): Improving tatonnement methods for solving heterogeneous agent models. Unpublished manuscript, MEA, University of Mannheim.

Lührmann, M. (2003): Demographic change, foresight and international capital flows. Discussion Paper 38-03, MEA, University of Mannheim.

Modigliani, F. and R. Brumberg (1954): Utility analysis and the consumption function: An interpretation of cross-section data. In K.K. Kurihara (ed.): Post-Keynesian Economics. New Brunswick: Rutgers University Press, 388-436.

Nataraj, S., und J. B. Shoven (2003), Comparing the Risks of Social Security with and without Individual Accounts, American Economic Review, Papers and Proceedings, 92, 348-353.

Obstfeld, M. (1986): Capital mobility in the world economy: Theory and measurement. Carnegie-Rochester Series on Public Policy, 24.

Obstfeld, M. and K. Rogoff (1996): Foundations of international macroeconomics, MIT Press, Cambridge, MA.

Obstfeld, M. and K. Rogoff (2000): The six major puzzles in international macroeconomics: Is there a common cause? NBER Macroeconomics Annual, 15, 339-390.

OECD (2003). STAN database. Paris: OECD.

OECD (2006): OECD Factbook 2006, http://www.oecd.org.

OECD (2007): OECD Health Data 2007, http://www.oecd.org.

Oliner, S., G. Rudebusch, and D. Sichel (1995): New and old models of business investment: A comparison of forecasting performance. Journal of Money, Credit and Banking, 27 (3), 806-826.

Palacios, R. and M. Pallarès-Miralles (2000): International patterns of pension provision. Social Protection Discussion Paper Series No. 0009, The World Bank, Washington, D.C.

Pemberton, J. (1999): Social security: National policies with international implications. Economic Journal, 109, 492-508. 
Pemberton, J. (2000): National and international privatization of pensions. European Economic Review, 44, 1873-1896.

Portes, R. and H. Rey (2005): The determinants of cross-border equity flows. Journal of International Economics, 65 (2), 269-296.

Poterba, J.M. (2001): Demographic structure and assets returns. Review of Economics and Statistics, 83(4), 565-584.

Razin, A. and E. Sadka (1999): Migration and pension with international capital mobility. Journal of Public Economics, 74, 141-150.

Reisen, H. (2000): Pensions, Savings and Capital Flows: From Aging to Emerging Markets. Cheltenham, UK: Edward Elgar.

Rios-Rull, J.-V. (1996): Life-cycle economies and aggregate fluctuations. Review of Economic Studies, 63(3), 465-489.

Rios-Rull, J.-V. (2001): Population changes and capital accumulation: The aging of the baby boom. Advances in Macroeconomics, 1(1), Article 7.

Samuelson, P.A. (1958): An exact consumption-loan model of interest with or without social contrivance of money. Journal of Political Economy, 66, 467-482.

Skirbekk, V. (2004): Population Aging and Productivity, Working paper of the Max Planck Institute for Demographic Research, Rostock, Germany.

Storesletten, K., C. (2000): Sustaining fiscal policy through immigration. Journal of Political Economy, 108, 300-323.

Taylor, A.M. (1994): Domestic saving and international capital flows reconsidered. Working Paper No. 4892, National Bureau of Economic Research (NBER).

United Nations Population Division (2001): World Population Prospects: The 2000 Revision. New York: United Nations.

U.S. Census Bureau, Population Division (2008): http://www.census.gov/ipc/www/idb/.

World Bank (2003): World Development Indicators, The World Bank, Washington, D.C..

World Health Organization (2007): Healthy Life Expectancy, http://www.who.int/whosis/ indicators/2007HALE0/en/.

Yaari, M.E. (1965): Uncertain lifetime, life insurance, and the theory of the consumer. Review of Economic Studies, 32(2), 137-150. 